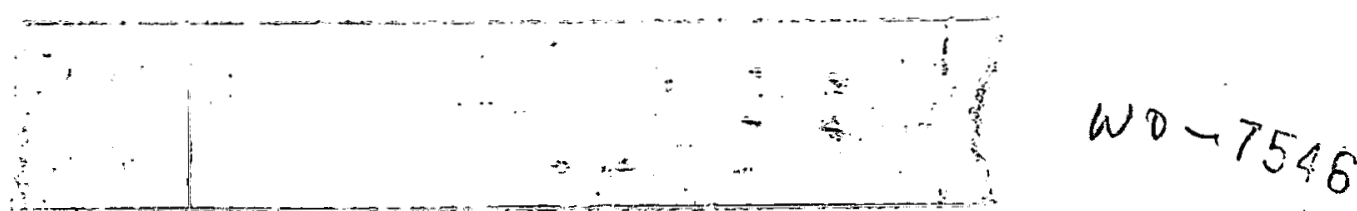

\title{
STUDIES IN THE CARBONATE-URANIUM SYSTEM
}

PART III

SPECTROPHOTOMETRIC INVESTIGATION OF

THE CARBONATE-URANYL COMPLEXES

C. A. Blake

R. S. Lowrie

K. B. Brown

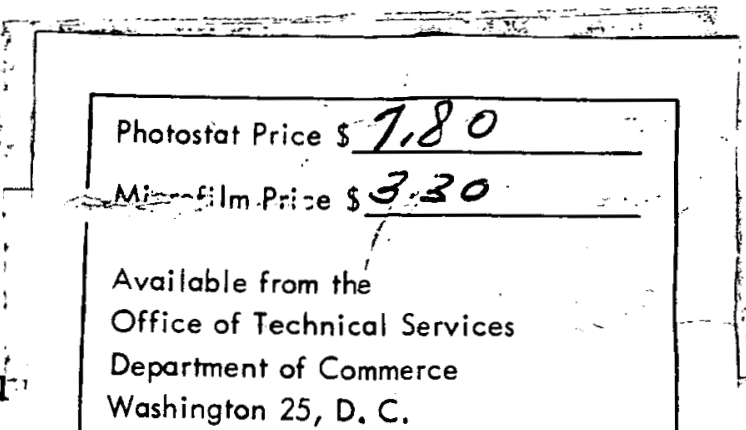

August 20, 1951

Washington 25, D. C.

\section{URANIUM CHEMISTRY OF RAW MATERIALS SECTION}

\section{LEGAL NOTICE}

This report was prepared as an account of Government sponsored work. Neither the United States, nor the Commission, nor any person acting on behalf of the Commission:

A. Makes any warranty or representation, express or implied, with respect to the accuracy, completeness, or usefulness of the informotion contained in this report, or that the use of any information, opparotus, method, or process disclosed in this report may not infringe privately owned rights; or

B. Assumes any liabilities with respect to the use of, or for damages resulting from the use of any information, apparatus, method, or process disclosed in this report.

As used in the above, "person acting on behalf of the Commission" includes any employee or contractor of the Commission to the extent that such employee or controctor prepares, handles or distributes, or provides access to, any informotion pursuant to his employment or contract with the Commission.

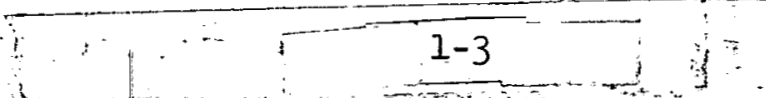




\section{DISCLAIMER}

This report was prepared as an account of work sponsored by an agency of the United States Government. Neither the United States Government nor any agency Thereof, nor any of their employees, makes any warranty, express or implied, or assumes any legal liability or responsibility for the accuracy, completeness, or usefulness of any information, apparatus, product, or process disclosed, or represents that its use would not infringe privately owned rights. Reference herein to any specific commercial product, process, or service by trade name, trademark, manufacturer, or otherwise does not necessarily constitute or imply its endorsement, recommendation, or favoring by the United States Government or any agency thereof. The views and opinions of authors expressed herein do not necessarily state or reflect those of the United States Government or any agency thereof. 


\section{DISCLAIMER}

Portions of this document may be illegible in electronic image products. Images are produced from the best available original document. 


\begin{abstract}
1

Additional evidence for the existence in solution of
\end{abstract} the uranyl tricarbonate ion, $\mathrm{UO}_{2}\left(\mathrm{CO}_{3}\right)_{3}^{-4}$, has been obtained by continuous variation spectrophotometric methods. Evidence has also been obtained for the presence in sodium. carbonate solutions of two additional complex ions having carbonate to uranium combining ratios of 0.5 and 2.0 . Though not uniquely proven, the ionic compositions appear to be $\mathrm{UO}_{2}\left(\mathrm{CO}_{3}\right)_{2}^{-2}$, dicarbonate ion, and $\mathrm{U}_{2} \mathrm{O}_{5} \mathrm{OHCO}_{3}-$, semicarbonate ion. The stability of these ions in salt solutions and the effect of hydrogen ion concentration have been studied.

Concentrations of each of these ions in various solutions have been estimated by a method which involves the measurement of the pressure of $\mathrm{CO}_{2}$ over these solutions and subsequent calculation of the amount of uncomplexed carbonate in solution.

Using these data, approximations have been made of the extent of the dissociation of the tricarbonate ion and the dicarbonate ion'iaccording to the following mechanisms:

$$
\begin{aligned}
& \mathrm{UO}_{2}\left(\mathrm{CO}_{3}\right)_{3}{ }^{-4} \stackrel{\mathrm{K}_{3}}{\rightleftarrows} \mathrm{UO}_{2}\left(\mathrm{CO}_{3}\right)_{2}{ }^{-2}+\mathrm{CO}_{3}^{-2} \\
& \mathrm{~K}_{3} \cdot=4.5 \times 10^{-7} \\
& 2 \mathrm{UO}_{2}\left(\mathrm{CO}_{3}\right)_{2}{ }^{-2}+2 \mathrm{H}_{2} \mathrm{O} \stackrel{\mathrm{K}_{2}}{\rightleftarrows} \mathrm{U}_{2} \mathrm{O}_{5} \mathrm{OHCO}_{3}+3 \mathrm{HCO}_{3} ; \\
& \mathrm{K}_{2}=8.4 \times 10^{-8}
\end{aligned}
$$




\section{SPECTROPHOTOMETRIC INVESTIGATION OF}

THE CARBONATE-URANYL COMPLEXES

\section{INTRODUCTION}

The preparation of sodium uranyl tricarbonate, the characteristics of its absorption spectrum, and the fact that tricarbonate solutions follow Beer's law have been reported. 1 The optical evidence in the present report also confirms the previously published 1 experimental verification of the existence in solution of a carbonate complex having a carbonate-uranium combining ratio of 3 .

Solutions having mole ratios of $\mathrm{CO}_{3} / \mathrm{U}=2$ and $\mathrm{Na} / \mathrm{U}=2$ can be prepared by contacting excess uranyl carbonate with sodium carbonate solution, the resulting concentration of the uranium depending on the sodium carbonate concentration. 2 A solid having a composition corresponding to these mole ratios has not been obtained, nor has the existence of an ion having a $\mathrm{CO}_{3} / \mathrm{U}$ combining ratio of 2 been reported previously and yet, solutions have been prepared which are over one molar in uranium and which still maintain these same mole ratios. These solubility data now have been made more significant by the fact that absorption spectrophotometric methods have given good evidence for the existence in solution of a uranyldicarbonate complex ion.

For solutions with $\mathrm{CO}_{3} / \mathrm{U}$ and $\mathrm{Na} / \mathrm{U}$ nearly equal to 2 and having moderate uranium concentrations ( 0.1 to 0.3 molar) the optical density varies nearly linearly with uranium concentration. However, at lower concentrations $(<0.05$ molar) a Beer's law plot shows a definite increase in slope as the solution becomes more dilute, the value of the slope depending upon the exact composition of the solution. This increase of slope upon dilution can be explained by the formation of a small but increasing amount of a colored complex having a rather large molar extinction. Since the extinctions for the di and tricarbonate ions have been found to be small, it is not unlikely that these data indicate the formation of a third 
colored complex of uranium and carbonate.

As an extension of previous work with the carbonateuranium system, 2 it has been of interest to identify so far as possible these uranium complexes and to determine some of their properties. Accordingly, the following spectrophotometric investigations, applying a method of continuous variations, were undertaken.

\section{EXPER I MENTAL}

\section{Apparatus}

The light absorption measurements were made with a Beckman Model DU Spectrophotometer using a tungsten lamp and silica cells having light paths ranging from $1 \mathrm{~mm}$ to $10 \mathrm{~cm}$.

A Beckman pH meter, Model G, equipped with glass and saturated calomel electrodes was used for the pH determinations.

Preparation of $\mathrm{UO}_{2} \mathrm{CO}_{3}$ and $\mathrm{Na}_{4} \mathrm{UO}_{2}\left(\mathrm{CO}_{3}\right)_{3}$

Uranyl carbonate, $\mathrm{UO}_{2} \mathrm{CO}_{3}$, was prepared by reacting a water slurry of $\mathrm{UO}_{3}$ with $\mathrm{CO}_{2}$ at increased temperatures and pressures.

Sodium uranyl tricarbonate, $\mathrm{Na}_{4} \mathrm{UO}_{2}\left(\mathrm{CO}_{3}\right)_{3}$, was prepared by reacting freshly precipitated $\mathrm{Na}_{2} \mathrm{U}_{2} \mathrm{O}_{7}$ with $\mathrm{NaHCO}_{3}$ solution under an atmosphere of $\mathrm{CO}_{2}$. The tricarbonate is obtained by crystallization.

Detailed accounts of the preparation of each of these compounds have been presented previous 1 y. 2

Preparation of Uranium Solutions

Preparation of solutions of sodium uranyl tricarbonate and of uranyl carbonate in sodium carbonate followed the procedure described in a previous report of this series. 3

\section{RESULTS AND DISCUSSION}

If a complex compound is formed by the addition of one agent to another, there are cases in which the data required for the type of continuous variation plot described by Job and Vosburgh 4 are difficult to obtain experimentally. This 
method requires the mixture, at equal molar concentrations, of varying quantities of solutions of the ion to be complexed and of the complexing agent. If precipitation results from such a mixing, then it is impossible to obtain the true optical density of the solution. In such cases, an alternate approach can be used which involves consideration of the ratio of the molar concentration of the complexing agent to a constant molar concentration of the substance to be complexed. 5 For interpretation, this ratio as measured for a series of solutions is plotted against the optical density of those solutions at a constant wavelength. On such plots changes of slope are indicative of changes in species, while maxima, minima, and inflections occur at ratios which correspond to the combining ratios of the complex species. In the tests, described below, solutions have been examined which have carbonate to uranium mole ratios varying from $\mathrm{CO}_{3} / \mathrm{U}=0$ to $\mathrm{CO}_{3} / \mathrm{U}=40$.

A series of solutions with $\mathrm{CO}_{3} / \mathrm{U}$ less than 3.0 were prepared by the addition of varying amounts of hydrochloric acid to solutions of sodium uranyl tricarbonate. Immediately upon addition of the acid, the solutions were scrubbed with moist nitrogen gas until a constant and reproducible optical density was obtained. During this scrubbing, the $\mathrm{pH}$ of the solution rose gradually and in many cases precipitation occurred shortly after a constant optical density was reached. For solutions having a ratio greater than 3.0 , sodium carbonate in the desired amount was added to sodium uranyl-tricarbonate solutions. The final pH of each solution was measured and its absorption spectrum and chemical analysis were obtained.

Following this procedure, the data shown in Table 1 and represented on Figure 1 were obtained. Figuré 1 shows the optical densities of solutions having a constant uranium concentration of 0.035 molar and carbonateuranium mole ratios varying from $\mathrm{CO}_{3} / \mathrm{U}=4.5$ to $\mathrm{CO}_{3} / \mathrm{U}=0.02$.

The existence of the tricarbonate complex found previously is again shown by the inflection at $\mathrm{CO}_{3} / \mathrm{U}=3.0$. Moreover, it appears that at ratios greater than 3.0 no further complex ions are formed since Table 2 shows that there is almost no change in the color of solutions having carbonate-uranium ratios ranging from $\mathrm{CO}_{3} / \mathrm{U}=3$ to $\mathrm{CO}_{3} / \mathrm{U}=$ 40 . 
Table 1

Optical Densities of Solutions Having

Varying Carbonate-Uranium Mole Ratios

Test Mole Ratio Number $\mathrm{CO}_{3} / \mathrm{U}$

311-11 0.00

$311-14 \quad 0.34$

$311-16 \quad 0.40$

311-13 0.50

31i-17 0.65

$311-10: 0.76$

$\begin{array}{ll}311-18 & 0.80\end{array}$

311-9:

0.83

311-19: 1.10

311-8: 1.18

311-7 1.31

311-21 1.61

$311-6 \cdot 1.63$

$311-22 \quad 1.84$

311-5

1.89

$311-23 \quad 1: 99$

311-4 2.07

311-24 2.10

$311-25 \quad 2.30$

$311 \div 3$
$\underline{\mathrm{pH}}$

1.0

5.3

5.8

7.8

8.2

6.9

8.2

7.8

8.3

7.9

8.2

8.4

8.4

8.8

8.6

8.6

8.5

8.7

8. 9

8. 8

8. 9

9.1

9.0

9. 3

9.3

3.17

311-0.

311-28

$311-26$
3.64
4.52

10.6

10.8 '
Optical Density ( $1 \mathrm{~cm}$ cell)

$420 \mathrm{~m} \mu \quad 430 \mathrm{~m} \mu \quad 440 \mathrm{m \mu} \quad 450 \mathrm{~m} \mu \quad 460 \mathrm{~m} \mu$

$\begin{array}{lllll}0.52 & 0.45 & 0.26 & 0.16 & 0.12\end{array}$

$2.54 \quad 2: 96$

2.76

2.20

1.45

2.70

3.24

3.15

2.60

1.80

2.60

3.47

3.80

3.62

2.92

2.50

3.34

3.76

3.68

3.00

\subsection{8}

3.30

3.72

3.68

2. 96

2. 34

3.14

3.04

2. 78

2.72

3.56

3. 48

3. 54

2.94

2.88

2. 0.6

3.18

3. 50

2.66

3. 14

3.24

2.56

1.86

2.44

2.82

3. 17

2.34

2. 14

2.46

2. 88

2.56

2. 04

1.64

2. 16

2.52

2. 62

2. 12

1.49

1. 90

2. 20

2. 32

1. 81

1.52

1.92

2. 24

2. 36

1. 94

1. 38

1.76

2. 16

2. 14

1.65

1.26

1.40

1.86

1.96

1. 50

1. 32

1.64

1.88

2. 00

1. 64

1.60

1. 70

1. 52

1.15

1.39

0.95

.86

.82

1.12

.70

1.27

1. 36

1.24
.98

.92

.73

.74

1. 12

1.04

1. 24

1. 14

0.98

0.98

.82

.85

0.93

77
.76

0.91

.79

.70

.52

.54

.68
.68

.76

.48 


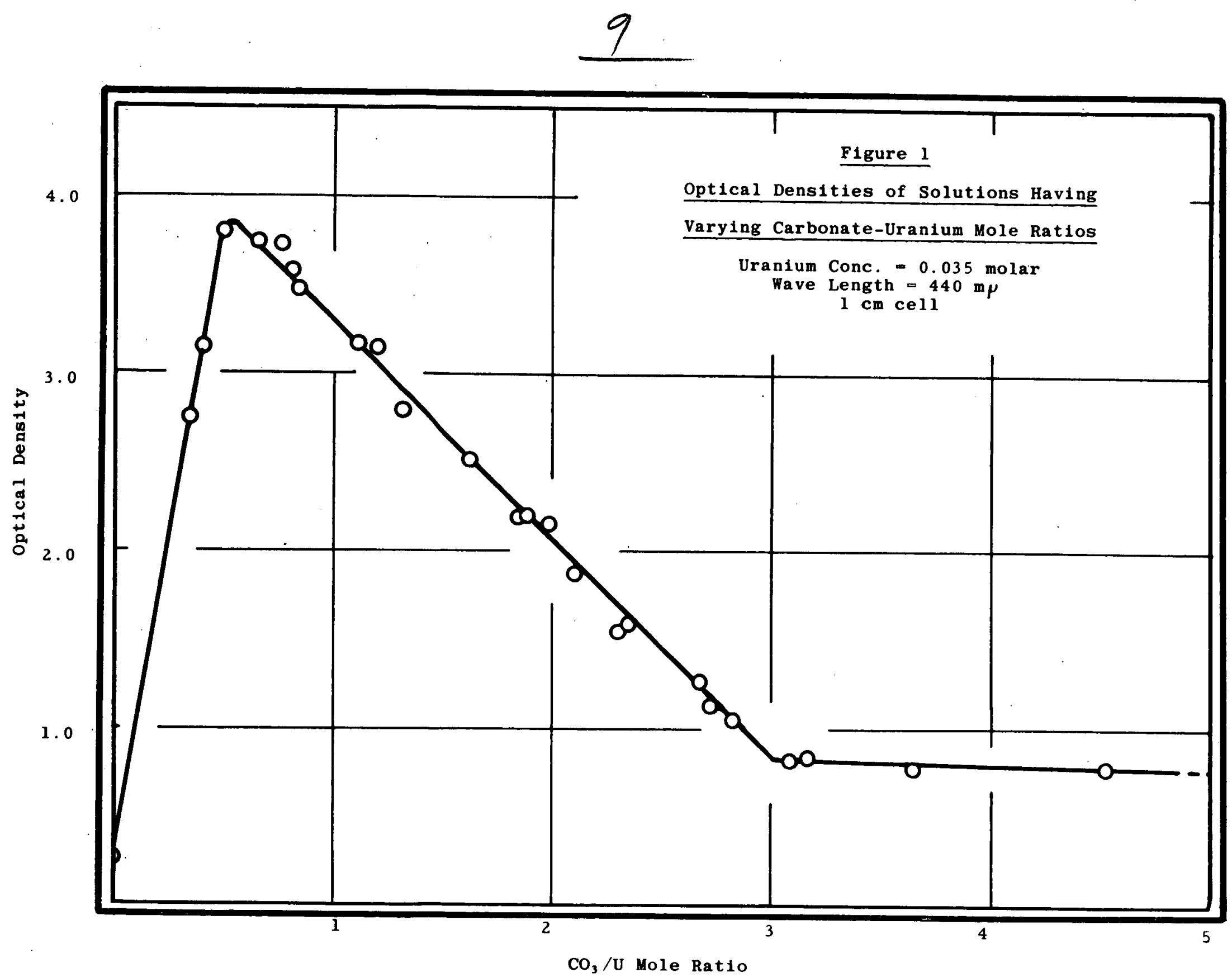


Tricarbonate solutions obey Beer's law for the concentration range 0.195 to 0.012 molar. These data appear in Table 3 and on Figure 2 .

The maximum in the curve of Figure 1 which occurs at $\mathrm{CO}_{3} / \mathrm{U}=0.5$ is of interest since it predicts a complex species having only one carbonate group associated with two uranium atoms. Since the pH of 7.8 possessed by this solution is well above the pH at which hydrolysis and dimerization of the uranyl ion take place, 6,7 and in view of the indicated low carbonate content of the complex, a semi-carbonate complex ion, $\mathrm{U}_{2} \mathrm{O}_{5} \mathrm{OHCO}_{3}-$, has been assumed as a definite possibility. Indeed, the amount of acid required by experiment ( 3.5 moles $\mathrm{HCl} / \mathrm{mole}$ of uranium) for the preparation of the solution having $\mathrm{CO}_{3} / \mathrm{U}=0.5$ allows a balanced equation to be written which shows the formation of such an ion.

$$
2 \mathrm{UO}_{2}\left(\mathrm{CO}_{3}\right)_{3}^{-4}+7 \mathrm{H}^{+} \longrightarrow \mathrm{U}_{2} \mathrm{O}_{5} \mathrm{OHCO}_{3}-+3 \mathrm{H}_{2} \mathrm{O}+5 \mathrm{CO}_{2}
$$

The possibility remains also that the following equation holds,

$$
4 \mathrm{UO}_{2}\left(\mathrm{CO}_{3}\right)_{3}^{-4}+14 \mathrm{H}^{+} \rightarrow \mathrm{U}_{4} \mathrm{O}_{11}\left(\mathrm{CO}_{3}\right)_{2}^{-2}+7 \mathrm{H}_{2} \mathrm{O}+10 \mathrm{CO}_{2}
$$

where the polymer, $\mathrm{U}_{4} \mathrm{O}_{11}\left(\mathrm{CO}_{3}\right)_{2}^{-2}$, differs from the monomers: $2 \mathrm{U}_{2} \mathrm{O}_{5} \mathrm{OHCO}_{3}-$, by one molecule of water. The formation of ions having a still higher degree of polymerization is unlikely in view of the acid requirements. These same acid requirements show that bicarbonate or hydroxy-bicarbonate complexes are stoichiometrically impossible in these solutions. The determination of the molecular weight of this semi-carbonate ion would be helpful in its identification, and accordingly, experiments were undertaken which applied the method of dialysis. 8 This method was known to give fair results when used with uranyl tricarbonate solutions, but no diffusion was observed through cellophane with solutions having $\mathrm{CO}_{3} / \mathrm{U}=0.5$. Further work is indicated along these lines and the application of the methods of electrodialysis 9 and cryoscopy. should be considered.

Figure 1 shows no inflection at $\mathrm{CO}_{3} / \mathrm{U}=2$, whereas the solubility of $\mathrm{UO}_{2} \mathrm{CO}_{3}$ in $\mathrm{Na}_{2} \mathrm{CO}_{3}$ solutions suggests the possibility of the existence of a dicarbonate complex ion. A previous report ${ }^{2}$ has described the preparation of solutions having carbonate-uranium and sodium-uranium mole ratios of 
Table 2

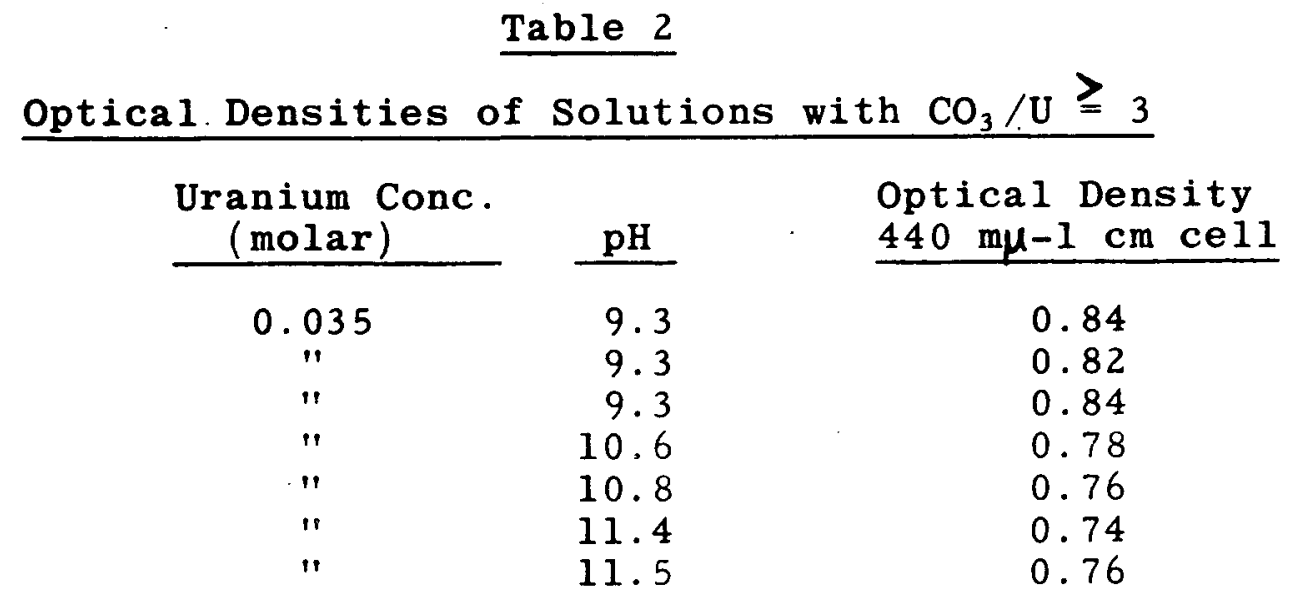

$\underline{\mathrm{CO}_{3} / \mathrm{U}}$

3.0

3.08

3.17

3.64

4.52

20

40

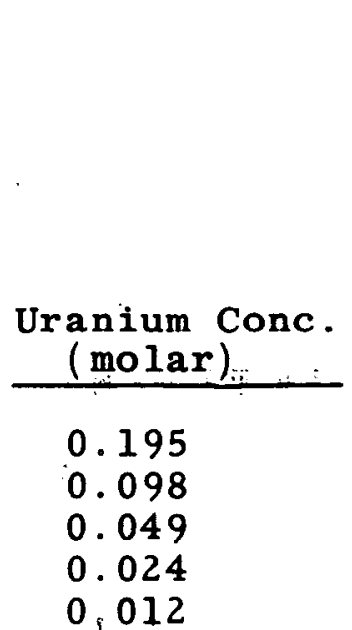

\begin{abstract}
Table 3
Beer's Law Data for Sodium Uranyl

Tricarbonate Solutions

Beer's Law Data for Sodium Urany 1
\end{abstract}

Uranium Conc.

molar
0.195
0.098
0.049
0.024
0.012

Optical Density ( $1 \mathrm{~cm}$ cell)

\begin{tabular}{|c|c|c|c|c|}
\hline $420 \mathrm{m \mu}$ & $430 \mathrm{~m} \mu$ & $440 \mathrm{m \mu}$ & $450 \mathrm{m \mu}$ & $460 \mathrm{m \mu}$ \\
\hline $\begin{array}{l}3.62 \\
1.84 \\
0.92 \\
0.50 \\
0.28\end{array}$ & $\begin{array}{l}3.72 \\
1.90 \\
0.96 \\
0.50 \\
0.28\end{array}$ & $\begin{array}{l}4.22 \\
2.16 \\
1.08 \\
0.56 \\
0.32\end{array}$ & $\begin{array}{l}5.08 \\
2.60 \\
1.30 \\
0.68 \\
0.36\end{array}$ & $\begin{array}{l}2.66 \\
1.34 \\
0.68 \\
0.36 \\
0.20\end{array}$ \\
\hline
\end{tabular}




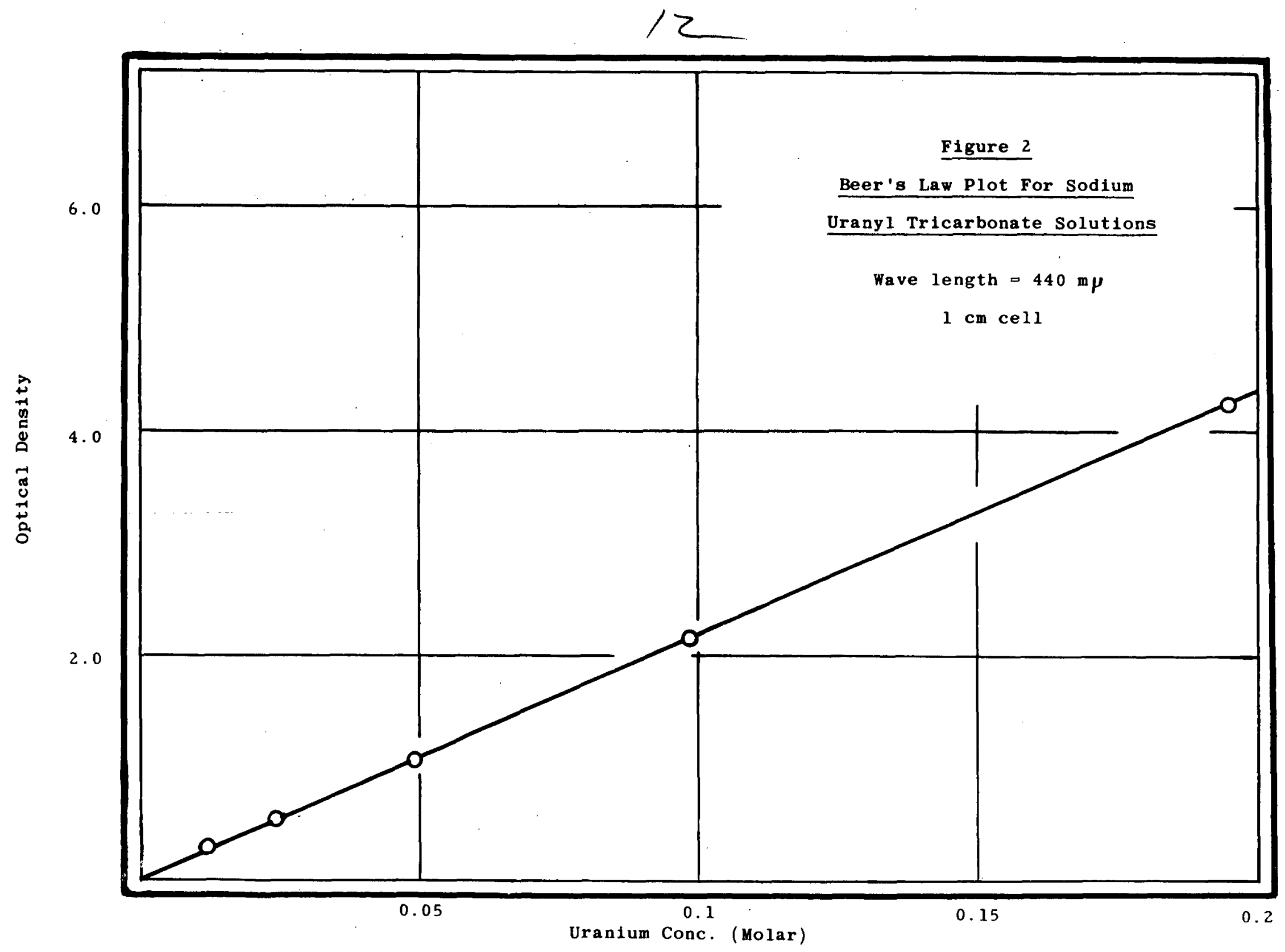


2.0. These are obtained by contacting excess solid uranyl carbonate with solutions of sodium carbonate, the resulting uranium concentration depending on the sodium carbonate concentration. Optical measurements on these solutions yield data such as is presented in Table 4. A typical Beer's law plot, constructed from these data, appears on Figure 3 . For concentrations greater than 0.017 molar the slope of this curve is nearly. linear while at lower concentrations there is a definite non-linearity. That these optical data require the presence of a third complex ion and that these dicarbonate solutions are not merely mixtures of tricarbonate and semi-carbonate in the proportions required to give $\mathrm{CO}_{3} / \mathrm{U}=\mathrm{Na} / \mathrm{U}=2$ is shown in the following discussion.

Assume a solution containing only the two complex ions, semi-carbonate and tricarbonate, with an equilibrium such as the following between the two species

$$
2 \mathrm{UO}_{2}\left(\mathrm{CO}_{3}\right)_{3}^{-4}+2 \mathrm{H}_{2} \mathrm{O} \rightarrow \mathrm{U}_{2} \mathrm{O}_{5} \mathrm{OHCO}_{3}^{-}+3 \mathrm{HCO}_{3}^{-}+2 \mathrm{CO}_{3}^{-2}
$$

a constant for this equilibrium can be written as

$$
\mathbf{K}_{3}^{\prime}, \mathbf{n}=\left(\mathrm{C}_{\mathrm{HCO}_{3}-}\right)^{3}\left(\mathrm{C}_{\mathrm{CO}_{3}-2}\right)^{2} \frac{\mathrm{Cn}_{\mathrm{n}}}{\left(\mathrm{C}_{3}\right)^{2}}
$$

where $C_{n}=$ molar concentration of semi-carbonate

$$
C_{3}=\text { molar concentration of tricarbonate }
$$

Introduction of the first and second dissociation constants of carbonic acid reduces the above expression to

$$
\mathrm{K}_{3}, \mathrm{n} \simeq \frac{\mathrm{c}_{\mathrm{n}}}{\left(\mathrm{c}_{3}\right)_{2}}
$$

where $\mathrm{K}_{3}, \mathrm{n}$ is also a function of hydrogen ion concentration and dissolved $\mathrm{CO}_{2}$, which quantities are nearly constant for these dicarbonate solutions. An approximate evaluation of this function shows that $K_{3}, n$ is a very large number (several positive powers of 10 ). 
$\underline{\text { Table } 4}$

Beer's Law Data for Solutions Having

$\mathrm{CO}_{3} / \mathrm{U}$ and $\mathrm{Na} / \mathrm{U}$ Very Nearly Equal to $2.0^{*}$

Optical Density ( $1 \mathrm{~cm}$ cell)

Uranium Conc.

\begin{tabular}{|c|c|c|c|c|c|c|}
\hline (Molar) & pH & 420 & 430 & 440 & 450 & 460 \\
\hline 0.350 & 7.12 & 7.75 & 8.85 & 11.06 & 9.70 & 6.46 \\
\hline 0.175 & 7.18 & 4.04 & 4.73 & 5.85 & 5.21 & 3.53 \\
\hline 0.087 & 7.28 & 2.14 & 2.56 & 3.14 & 2.84 & 1.96 \\
\hline 0.44 & 7.44 & 1.22 & 1.48 & 1.78 & 1.63 & 1.15 \\
\hline 0.022 & 7.58 & 0.73 & 0.91 & 1.04 & 0.98 & 0.72 \\
\hline 0.011 & 7.75 & 0.45 & 0.57 & 0.64 & 0.60 & 0.44 \\
\hline $0: 005$ & 7.89 & 0.27 & 0.33 & 0.36 & 0.34 & 0.24 \\
\hline 0.003 & 8.10 & 0.15 & 0.19 & 0.20 & 0.18 & 0.13 \\
\hline 0.0014 & 8.50 & 0.08 & 0.09 & 0.10 & 0.08 & 0.06 \\
\hline 0.0067 & -- & 0.04 & 0.05 & 0.04 & 0.04 & 0.03 \\
\hline
\end{tabular}

*Actual Values

$\mathrm{CO}_{3} / \mathrm{U}=1.81$

$\mathrm{Na} / \mathrm{U}=.2 .08$ 


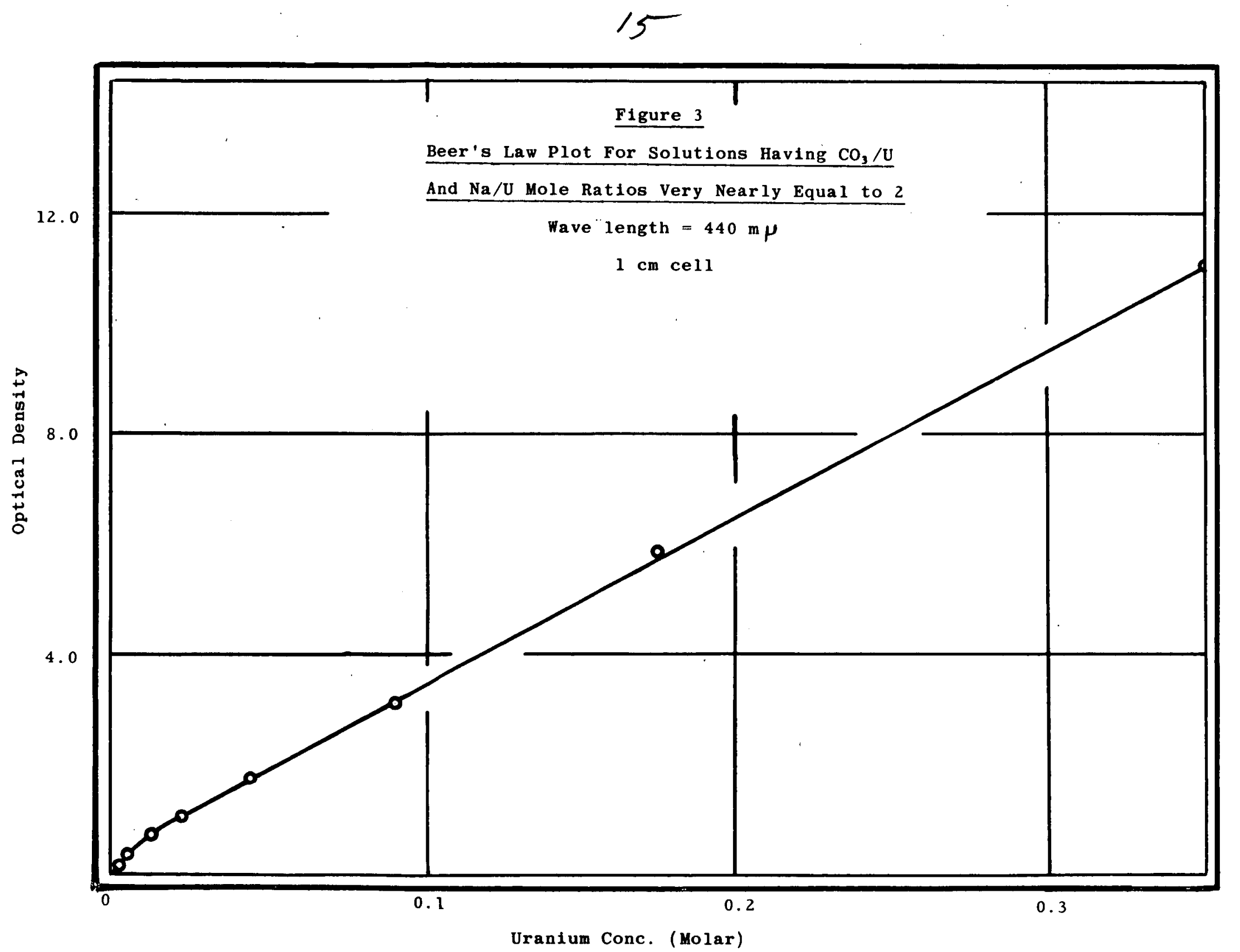


An expression for the total concentration of uranium in this solution may be written as

$$
C_{U}(\operatorname{tota} 1)=C_{3}+2 C_{n}
$$

solving equations (4a) and (5)

$$
\begin{gathered}
C_{3}=\frac{-1 \pm \sqrt{1+8 K_{3}, \mathrm{nCU}}}{4 \mathrm{~K}_{3}, \mathrm{n}} \\
\mathrm{C}_{\mathrm{n}}=\frac{\mathrm{C}_{\mathrm{U}}}{2}-\left[\frac{-1 \pm \sqrt{1+8 \mathrm{~K}_{3}, \mathrm{n} \mathrm{C}_{\mathrm{U}}}}{8 \mathrm{~K}_{3}, \mathrm{n}}\right]
\end{gathered}
$$

The equation for the optical density of this solution containing two colored species is

$$
\text { O.D. }=\boldsymbol{l}\left(\mathrm{E}_{3} \mathrm{C}_{3}+\mathrm{E}_{\mathrm{n}} \mathrm{C}_{\mathrm{n}}\right)
$$

where

$$
\begin{array}{ll}
\text { O.D. } & \text { Optical density } \\
\mathrm{E} & =\text { Molar extinction } / \mathrm{cm} \text { of solution } \\
& \text { of indicated species } \\
l & =\text { Length of light path in } \mathrm{cm} .
\end{array}
$$

Substitution in equation (8) for $C_{3}$ and $C_{n}$ leads to

$$
0 . D .=\ell\left[\frac{-1 \pm \sqrt{1+8 K_{3}, n C_{U}}}{4 K_{3}, n}\right]\left(E_{3}-\frac{E_{n}}{2}\right)+\ell \frac{E_{n}}{2} C_{U}
$$

Examination of equation (9) shows that at moderate concentrations the optical density should vary linearly with the total uranium concentration and the slope of the curve. showing this relationship should be

$$
\text { Slope }=\frac{l E_{n}}{2}
$$


Calculations using the data of Figure 1 for the point corresponding to semi-carbonate $\left(\mathrm{CO}_{3} / \mathrm{U}=0.5\right)$ shows that the molar extinction coefficient for semi-carbonate, $E_{n}$, must be at least 200 . This requires that the slope of the curve of Figure -3 be at least 100 . Measurement of the experimental slope shows it to be more nearly 34. Further experiments show that similar plots for solutuions having compositions slightly different (i.e., higher or lower sodium and carbonate) from those for which the data of Table 4 were taken have slopes which may vary from this value of 34 by +5 . It is apparent from this optical evidence that there must be present a third colored complex of carbonate and uranium having an extinction coefficient intermediate to those of the semi-carbonate and tri-carbonate ions. Moreover, the analytical data which always shows $\mathrm{CO}_{3} / \mathrm{U}$ and $\mathrm{Na} / \mathrm{U}$ very nearly equal to 2 assumes greater significance.

In making the solubility studies, loss of $\mathrm{CO}_{2}$ from dicarbonate solutions was observed. Accordingly, a series of dicarbonate solutions. was washed with moist nitrogen gas to aid in the removal of $\mathrm{CO}_{2}$. In this manner, solutions were prepared having $\mathrm{CO}_{3} / \mathrm{U}$ mole ratios ranging from 2.0 to 1.6. The optical density measurements on these solutions appear in Table 5. To this carbonate depleted solution increasing amounts of uranyl tricarbonate solution were added in a further attempt to show the presence of a dicarbonate complex. The data for these tests appear in Table 6 and a plot of these results in which $\mathrm{CO}_{3} / U$ varies from 1.7 to 3.1 will show no inflection at a combining ratio of 2. 0 .

Failure to obtain by continuous variation methods any significant evidence for a dicarbonate ion gave rise to a closer examination of the compositions of certain of the solutions used in the experimental studies. (Table 7). These are three solutions with identical uranium concentrations and carbonate-uranium ratios, but having different optical densities and pH values. Reasonable explanations for these variations may be found in equations describing the probable reactions in the solutions.

Case I: Formation of uranyl dicarbonate from $\mathrm{UO}_{2} \mathrm{CO}_{3}$ and $\mathrm{Na}_{2} \mathrm{CO}_{3}$

$$
\mathrm{UO}_{2} \mathrm{CO}_{3}+\mathrm{Na}_{2} \mathrm{CO}_{3} \rightarrow \mathrm{Na}_{2} \mathrm{UO}_{2}\left(\mathrm{CO}_{3}\right)_{2}
$$


Table 5

Optical Densities of Solutions Prepared from

Uranyl Dicarbonate Solutions By Removal

Of $\mathrm{CO}_{2}$ With A Nitrogen Gas Scrubbing

\begin{tabular}{|c|c|c|c|c|c|c|c|}
\hline Test & le $\mathrm{Ra}$ & & 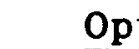 & cal D & asity & $\mathrm{cm}$ & \\
\hline Number & $\mathrm{CO}_{3} / \mathrm{U}$ & $\underline{\mathrm{pH}}$ & $420 \overline{\mathrm{mg}}$ & $430 \mathrm{mp}$ & $440 \mathrm{~m} \mu$ & $450 \mathrm{mp}$ & $460 \mathrm{mp}$ \\
\hline $1034-\mathrm{H}-1$ & 1.92 & 7.5 & 1.08 & 1.34 & 1.58 & 1.49 & 1.07 \\
\hline $1034-\mathrm{H}-2$ & 1.90 & 7.7 & 1.19 & 1.48 & 1.74 & 1.68 & 1.25 \\
\hline $1034-\mathrm{B}$ & 1.84 & 7.8 & 1.22 & 1.54 & 1.79 & 1.76 & 1.31 \\
\hline $1034-\mathrm{H}-4$ & 1.78 & 7.9 & 1.29 & 1.64 & 1.91 & 1.90 & 1.44 \\
\hline $1034-\mathrm{H}-5$ & 1.74 & 8.2 & 1.44 & 1.86 & 2.14 & 2.14 & 1.68 \\
\hline $1034-\mathrm{H}-6$ & 1.67 & 8.3 & 1.54 & 2.06 & 2.36 & 2.36 & 1.88 \\
\hline $1034-\mathrm{H}-7$ & 1.57 & 9.15 & 1.82 & 2.38 & 2.80 & 2.90 & 2.32 \\
\hline $1034-H-8$ & 1.57 & 8.98 & 1.82 & 2.40 & 2.82 & 2.90 & 2.28 \\
\hline $1034-\mathrm{H}-9$ & 1.60 & 8.84 & 1.78 & 2.36 & 2.73 & 2.80 & 2.22 \\
\hline $1034-\mathrm{H}-10$ & 1.60 & 8.65 & 1.74 & 2.34 & 2.66 & 2.72 & 2.14 \\
\hline $1034-\mathrm{H}$ & 1.59 & 9.20 & 1.82 & 2.40 & 2.79 & 2.90 & 2.28 \\
\hline $1034-\mathrm{H}-12$ & 1.56 & 9.15 & 1.84 & 2.42 & 2.80 & 2.91 & 2.34 \\
\hline
\end{tabular}

Uranium concentration $=0.035$ molar

Table 6

Optical Densities of Solutions Prepared by the Addition of Sodium Uranyl Tricarbonate To A Solution Having $\mathrm{A} \mathrm{CO}_{3} / \mathrm{U}$ Mole Ratio of 1.74

Test Mole Ratio Number $\mathrm{CO}_{3} / \mathrm{U}$

32 7-1

327-2

327-3

$327-4$

$327-5$

$327-8$

$327-10$
1.74

1.88

2.02

2.10

2.15

2.48

3.14
pH

$$
8.62
$$

8.67

8.72

8. 7.1

8.72

8.83

9.30

1.19

0.70

1.72

1.60

1.50

1.44

1.39

Optica 1 Density ( $1 \mathrm{~cm}$.cell)

Uranium concentration $=0.035$ molar 
Case II. Reaction of uranyl tricarbonate with HCl

$2 \mathrm{Na}_{4} \mathrm{UO}_{2}\left(\mathrm{CO}_{3}\right)_{3}+3 \mathrm{HCl} \rightarrow 2 \mathrm{Na}_{2} \mathrm{UO}_{2}\left(\mathrm{CO}_{3}\right)_{2}+3 \mathrm{NaCl}+\mathrm{NaHCO}_{3}+\mathrm{H}_{2} \mathrm{O}+\mathrm{CO}_{2}$

A solution of uranyl dicarbonate prepared as above and having the same uranium concentration as the solution of Case I will thus be complicated by the presence of $\mathrm{NaCl}$ and $\mathrm{NaHCO}_{3}$. The higher optical density of this solution cannot be explained by the presence of $\mathrm{NaCl}$ as the data of Table 8 shows no enhancement of color upon the addition of NaCl to carbonate solutions. It will be shown later that the addition of $\mathrm{NaHCO}_{3}$ to dicarbonate solutions decreases, rather than increases, the optical density. It must be remembered that the solution of Case II was scrubbed with nitrogen gas in order to remove $\mathrm{CO}_{2}$. This treatment also decomposed some of the $\mathrm{NaHCO}_{3}$ according to equation (13)

$$
2 \mathrm{NaHCO}_{3} \rightarrow \mathrm{Na}_{2} \mathrm{CO}_{3}+\mathrm{CO}_{2}+\mathrm{H}_{2} \mathrm{O}
$$

to give, in effect, an increase in the hydroxyl ion concentration of the solution. This increase permits further hydrolysis of the dicarbonate to form some of the semicarbonate, $\mathrm{NaU}_{2} \mathrm{O}_{5} \mathrm{OHCO}_{3}$, thereby increasing the solution color. In all of these solutions, too much bubbling with nitrogen produced a hydrolytic precipitate which, from observation and analysis, appeared to be a mixture of sodium uranates.

Case III. Addition of uranyl tricarbonate to a $\mathrm{CO}_{2}$ depleted uranyl dicarbonate solution.

In this case, a probable mechanism for the hydrolysis of uranyl dicarbonate in water must first be considered

$$
2 \mathrm{Na}_{2} \mathrm{UO}_{2}\left(\mathrm{CO}_{3}\right)_{2}+2 \mathrm{H}_{2} \mathrm{O} \rightarrow \mathrm{NaU}_{2} \mathrm{O}_{5} \mathrm{OHCO}_{3}+3 \mathrm{NaHCO}_{3}
$$

This solution should lose $\mathrm{CO}_{2}$ readily with the formation of $\mathrm{NaOH}$ or $\mathrm{Na}_{2} \mathrm{CO}_{3}$. Some of the latter can react with additional uranyl dicarbonate to form uranyl tricarbonate. If this formation is considered, equation (14) becomes

$3 \mathrm{Na}_{2} \mathrm{UO}_{2}\left(\mathrm{CO}_{3}\right)_{2}+\mathrm{H}_{2} \mathrm{O} \rightarrow \mathrm{NaU}_{2} \mathrm{O}_{5} \mathrm{OHCO}_{3}+\mathrm{Na}_{4} \mathrm{UO}_{2}\left(\mathrm{CO}_{3}\right)_{3}+\mathrm{NaHCO}_{3}+\mathrm{CO}_{2}$

Thus, on bubbling a uranyl dicarbonate solution with nitrogen, $\mathrm{CO}_{2}$ is lost, the final mole ratio of $\mathrm{CO}_{3} / \mathrm{U}$ remaining in 
$\underline{\text { Table } 7}$

Solutions Having $\mathrm{CO}_{3} / \mathrm{U}=2$ Prepared by Different Methods

(Uranium Concentration $=0,035$ Molar)

\begin{tabular}{|c|c|c|c|c|}
\hline Number & Source & $\begin{array}{c}\text { Mole Ratio } \\
\mathrm{CO}_{3} / \mathrm{U} \\
\end{array}$ & $\mathrm{pH}$ & $\begin{array}{l}\text { O.D. } 440 \mathrm{~m} \mu \\
1 \mathrm{~cm} \mathrm{ce} 11 \\
\end{array}$ \\
\hline I & Table 4 & 2 & 7.2 & 1.50 \\
\hline II & Table 1 & 2 & 8.6 & 1.94 \\
\hline I I I & Table 5 & 2 & 8.7 & 2.26 \\
\hline
\end{tabular}

Solution preparation:

I. Uranyl carbonate dissolved in sodium carbonate solution.

II. Tricarbonate solution decomposed with HCl and bubbled with nitrogen.

III. Addition of tricarbonate to dicarbonate solution depleted of $\mathrm{CO}_{2}$ by nitrogen bubbling.

Table 8

Optical Densities of Sodium Urany 1 Tricarbonate

Solutions in the Presence of Sodium Chloride

Test $\mathrm{NaCl}$ Conc.

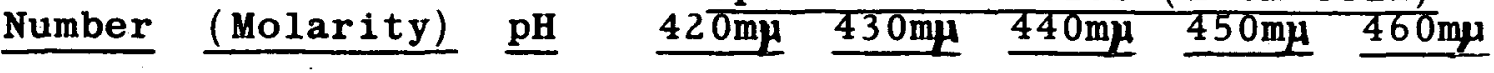

$\begin{array}{llllllll}1 & --- & 9.25 & 0.98 & 1.04 & 1.14 & 1.39 & 0.74 \\ 2 & 0.01 & 9.25 & 0.98 & 1.04 & 1.14 & 1.39 & 0.74 \\ 3 & 0.05 & 9.25 & 0.98 & 1.04 & 1.14 & 1.39 & 0.74 \\ 4 & 0.50 & 9.45 & 0.98 & 1.04 & 1.14 & 1.39 & 0.74\end{array}$

Uranium concentration $=0.0502$ molar 
solution being between $5 / 3>\mathrm{CO}_{3} / \mathrm{U}>4 / 3$, depending on how much of the bicarbonate decomposes before the $\mathrm{pH}$ becomes high enough for precipitation to occur. Table 5 shows that a limit of $4.8 / 3$ was reached experimentally. Addition of urany 1 tricarbonate in the correct amount to this depleted dicarbonate solution will then result in a solution having $\mathrm{CO}_{3} / \mathrm{U}=2.0$, but also having a $\mathrm{pH}$ value and optical density greater than those for the solutions of either Case I or Case II.

The effect of the hydrolysis described by equation (15) is shown also in the Beer's law data of Table 3 and Figure 2 . At uranium concentrations below $0.017 \mathrm{M}$ deviations from the straight line relationship of Beer's law begin and the resulting curve of optical density versus concentration has an increasingly greater slope as the uranium becomes more dilute. This may be accounted for by the formation of greater amounts of the highly colored semicarbonate complex, $\mathrm{NaU}_{2} \mathrm{O}_{5} \mathrm{OHCO}_{3}$.

It thus appears that the only factor causing the variations in color of the solutions of Case I, II, and III is the $\mathrm{pH}$. To test this assumption $\mathrm{NaOH}$ in small amounts was added to a uranyl dicarbonate solution, and as expected, the optical density increased. These data appear in Table 9. It is interesting that the addition of both acids and bases to a dicarbonate solution will cause an increase in the color of the solution. However, equations (12) and (13) show that after the first decomposition of the carbonate by acid the basic reaction products are responsible for the increase in color.

Table 9

Optical Densities of Solutions of Sodium

Uranyl Dicarbonate in the Presence of Small

Amounts of Sodium Hydroxide

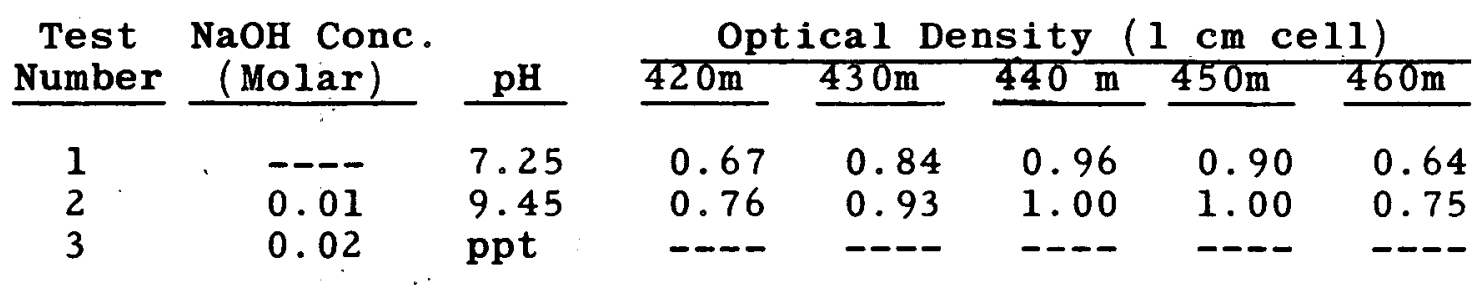

Uranium Concentration $=0.018$ molar 
Having established the dependence of color upon pH, a series of experiments were run in which the $\mathrm{pH}$ values of the solutions were kept at a specified constant level. The test procedure was similar to that used for the solutions described in Table 1 with the exception that the nitrogen bubbling was stopped at the predetermined $\mathrm{pH}$ level. The absorption spectrum and analysis of each solution were obtained at this point. As indicated in Table 10, the carbonate-uranium mole ratios for these solutions vary from $\mathrm{CO}_{3} / \mathrm{U}=1$ to $\mathrm{CO}_{3} / \mathrm{U}=3$ and plots are shown in Figure 4 for the two pH levels of 7.98 and 7.50. Under these conditions, inflections may be noted near a combining ratio of 2 , giving acceptable evidence for the existence in these solutions of a dicarbonate ion.

This same method, when applied to solutions having carbonate-uranium mole ratios ranging from 0.44 to 1.41 , again leads to a sharp maximum occuring at $\mathrm{CO}_{3} / \mathrm{U}=0.5$ on the continuous variation curve. These data are shown in Table 11 and in Figure 5.

Attempts to prepare solutions having carbonate-uranium mole ratios greater than 2 by the addition of $\mathrm{Na}_{2} \mathrm{CO}_{3}$ to uranyl dicarbonate solutions have proven unsuccessful since the $\mathrm{pH}$ increases so rapidly that precipitation occurs at a mole ratio of $\mathrm{CO}_{3} / \mathrm{U}$ greater than 2.5. Addition of $\mathrm{NaHCO}_{3}$ is more feasible and solutions having ratios ranging from 2 to 4 have been prepared by this method. The data for these solutions appear in Table 12 and in Figure 6. The inflection occuring on the continuous variation plot of this figure indicates an association of three carbonate groups with one uranium atom, but the properties of this series of solutions make it doubtful whether the tricarbonate ion may exist as such at the point of inflection. Due to its preparation from sodium uranyl dicarbonate and sodium bicarbonate, the solution which this point represents furnishes only threequarters of the sodium ions required to balance the four valent charge of the uranyl tricarbonate ion, and yet the acidity of the solution is not high enough to allow the presence of enough free hydrogen ions to make up this deficiency in charge balance. It becomes necessary, then, to consider the possible formation of a bicarbonate-carbonate complex of uranium in these less basic solutions, e.g., $\mathrm{HUO}_{2}\left(\mathrm{CO}_{3}\right)_{3}^{-3}$

It is interesting to compare the optical density of a tricarbonate solution (Test 1, Table 13) with the color of a solution of equal uranium concentration and carbonateuranium ratio as determined from Figure 6 . 
Test 1, Table 13

Uranium conc.

$\mathrm{CO}_{3} / \mathrm{U}$

pH

O.D. (440 mp-1 cm cell)

Preparation
0.035 molar

3.05

9.3

0.800

Tricarbonate
Figure 6

0.035 molar

3.05

7.9

0.780

Dicarbonate + $\mathrm{NaHCO}_{3}$

It may be observed that the optical densities of these solutions are nearly identical in spite of the differences in $\mathrm{pH}$ and in their methods of preparation. Thus, a differentiation between uranyl tricarbonate solutions and uranyl carbonate-bicarbonate solutions seems difficult by means of absorption methods using visible light. It is possible that studies in the invisible ranges of the absorption spectra of carbonate-bicarbonate and similar systems (sulfateacid sulfate, phosphate-acid phosphate) will yield information more clearly establishing the nature of the complex ion in these solutions. It is probably true when the pH level is near 9 , when the $\mathrm{CO}_{3} / \mathrm{U}$ mole ratio is 3 or greater, and when there is sufficient sodium ion in solution that the major complex between uranium and carbonate is the uranyl tricarbonate ion, $\mathrm{UO}_{2}\left(\mathrm{CO}_{3}\right)_{3}^{-4}$.

It has been demonstrated that the tricarbonate complex is stable over a wide range of carbonate concentration (Table 2), and in the presence of the chloride ion (Table 8). The data of Tables 13 and 14 also show its stability in the presence of excess bicarbonate ion and hydroxyl ion.

The foregoing discussion has presented evidence for the existence in solution of three uranium-carbonate complex ions. The first of these is the uranyl tricarbonate complex,

$$
\mathrm{UO}_{2}\left(\mathrm{CO}_{3}\right)_{3}^{-4}
$$

the second being a "semi-carbonate" complex,

$$
\mathrm{U}_{2} \mathrm{O}_{5} \mathrm{OHCO}_{3}^{-} \text {, }
$$

and a third, which will be called a "dicarbonate" complex.

Consideration may be given now to those solutions prepared by the dissolution of uranyl carbonate in sodium carbonate with a resulting $\mathrm{pH}$ very close to 7.0 and analyses 
Table 10

\section{Continuous Variation Data at Controlled pH}

\section{Levels for Solutions Having $2>\mathrm{CO}_{3} / \mathrm{U}>3$}

\section{Test Mole Ratio}

Number

329-1

$329-3$

$329-9$

$329-4$

$329-10$

$329-5$

$329-8$

329-1

$329-2$

$329-3$

$329-9$

$329-4$

$329-10$

$329-5$

329-8

\begin{tabular}{|c|c|}
\hline $\mathrm{CO}_{3} / \mathrm{U}$ & pH \\
\hline 2.96 & \\
\hline 2.42 & \\
\hline 2.04 & \\
\hline 1.82 & 5 \\
\hline 1.47 & 7 \\
\hline 1.35 & 7.5 \\
\hline 1.06 & \\
\hline
\end{tabular}

2.91

2.87

2.24

1.93

1.75

1.42

1.25

1.00

7.98

7.98

7.98

7.98

7.98

7.98

7.98

7.98
Optical Density ( $1 \mathrm{~cm}$ cell) $4 \overline{30 \mathrm{mp}} \quad$ 440mp $450 \mathrm{mp} \quad 460 \mathrm{mp}$

0.66

0.81

0.86

0.41

1.02

1. 24

1.18

0.86

1. 33

1.55

1. 54

1. 57

1. 12

1. 38

2. 20

2. 46

2. 44

1. 15

2. 34

2. 64

2. 54

1. 96

2. 96

3. 24

3.06

2. 00

2.46

0.77

0.80

0.92

1. 30

0.95

0.94

0.99

0.55

1. 65

1. 54

1.42

1. 98

1. 80

2. 52

2. 52

3.04

1. 88

2. 08

2.82

2. 12

2. 87

2. 98

3. 34

3. 44

1. 15

1. 55

1.65

2. 30

2.40

2. 72

Uranium concentration $=0.035$ molar 
25

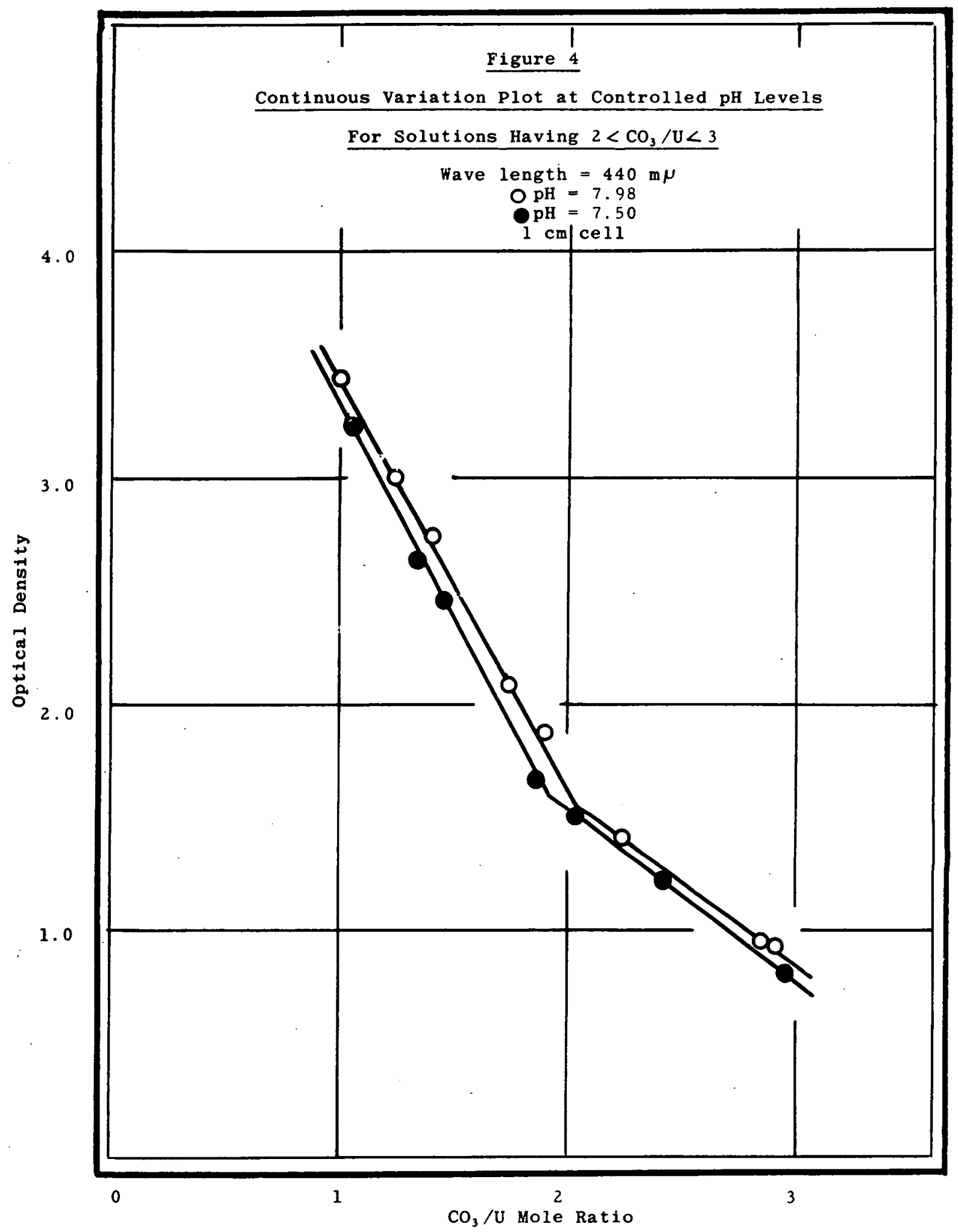




\section{Table 11}

\section{Continuous Variation Data At Controlled pH Levels \\ For Solutions Having $0.4<\mathrm{CO}_{3} / \mathrm{U}<1.4$}

Test

Number

$329-14$

$329-15$

$329-16$

$329-17$
$\mathrm{CO}_{3} / \mathrm{U}$

1.41

$\underline{\mathrm{pH}}$

5.8

0.83

5.8

0.49

5.7

0.44

5.7
Optical Density ( $1 \mathrm{~cm}$ cell)

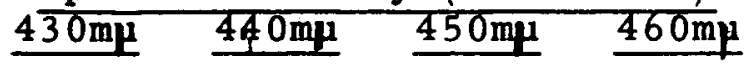

2.68

2.74

2.36

1.65

3.16

3.21

2.80

2.04

3.32

3.22

2.64

1.82

3.10

2.84

2.32

1.50 


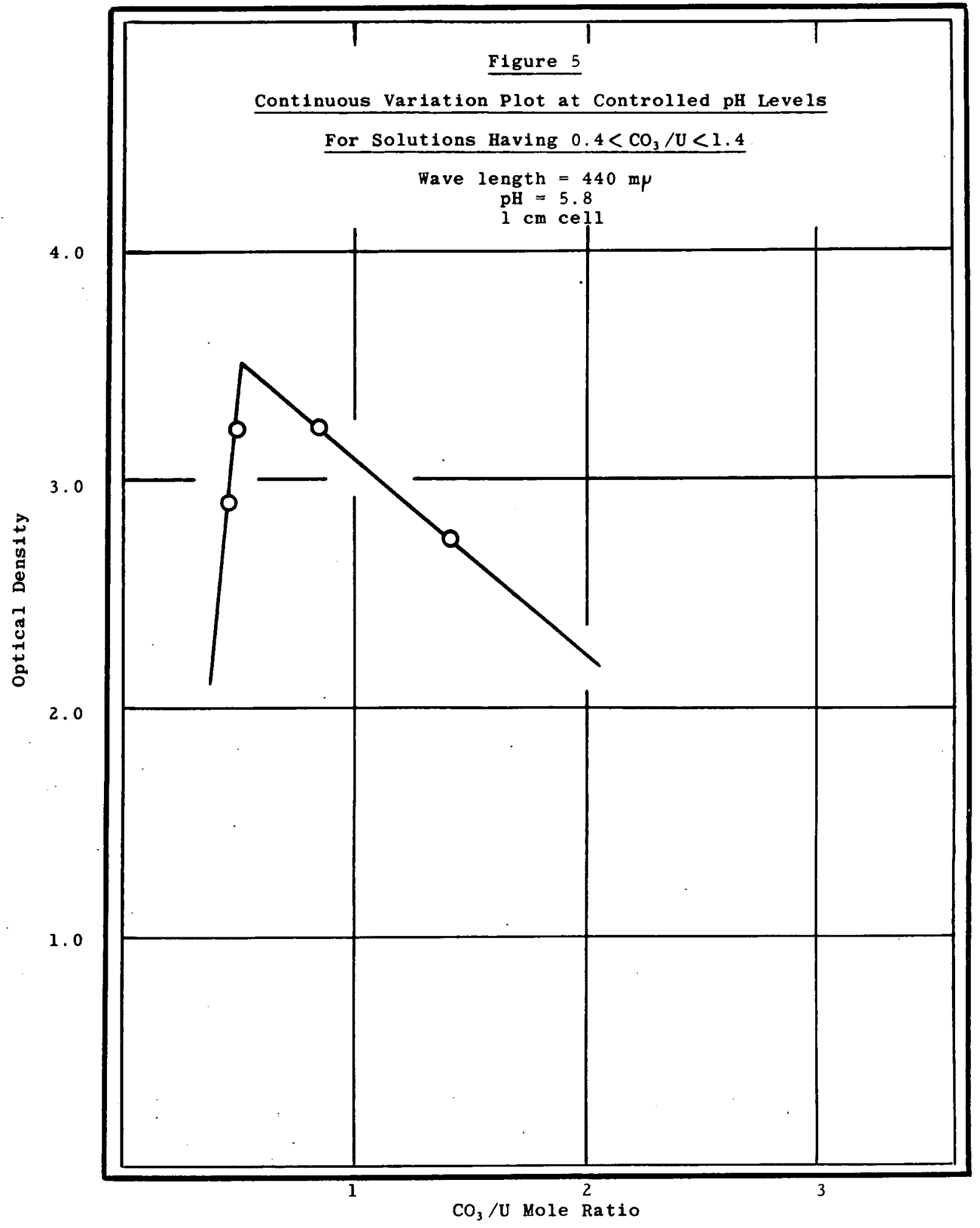


Table 12

Continuous Variation Data For Solutions Prepared

By The Addition of $\mathrm{NaHCO}_{3}$ To Urany 1 Dicarbonate Solutions

\begin{tabular}{cccccccc}
$\begin{array}{c}\text { Test } \\
\text { Number }\end{array}$ & $\begin{array}{c}\text { Mole Ratio } \\
\mathrm{CO}_{3} / \mathrm{U}\end{array}$ & pH & & \multicolumn{4}{c}{ Optical Density $(1 \mathrm{~cm}$ ce 11$)$} \\
\hline $334-0$ & 1.83 & 7.9 & & 1.73 & 1.98 & 1.96 & 1.47 \\
$334-9$ & 1.96 & 7.9 & 1.58 & 1.84 & 1.80 & 1.36 \\
$334-4$ & 2.04 & 7.9 & 1.41 & 1.66 & 1.61 & 1.17 \\
$334-2$ & 2.09 & 7.9 & 1.45 & 1.66 & 1.70 & 1.24 \\
$334-7$ & 2.52 & 7.9 & 0.93 & 1.17 & 1.04 & 0.67 \\
$334-5$ & 2.72 & 7.9 & 0.74 & 0.91 & 0.90 & 0.53 \\
$334-1$ & 2.75 & 7.9 & 0.75 & 0.93 & 0.88 & 0.53 \\
$334-3$ & 3.00 & 7.9 & 0.70 & 0.86 & 0.87 & 0.49 \\
$334-6$ & 3.38 & 7.9 & 0.65 & 0.77 & 0.86 & 0.44 \\
$334-8$ & 4.20 & 7.9 & 0.66 & 0.75 & 0.92 & 0.46
\end{tabular}

Uranium Concentration $=0.035$ molar 


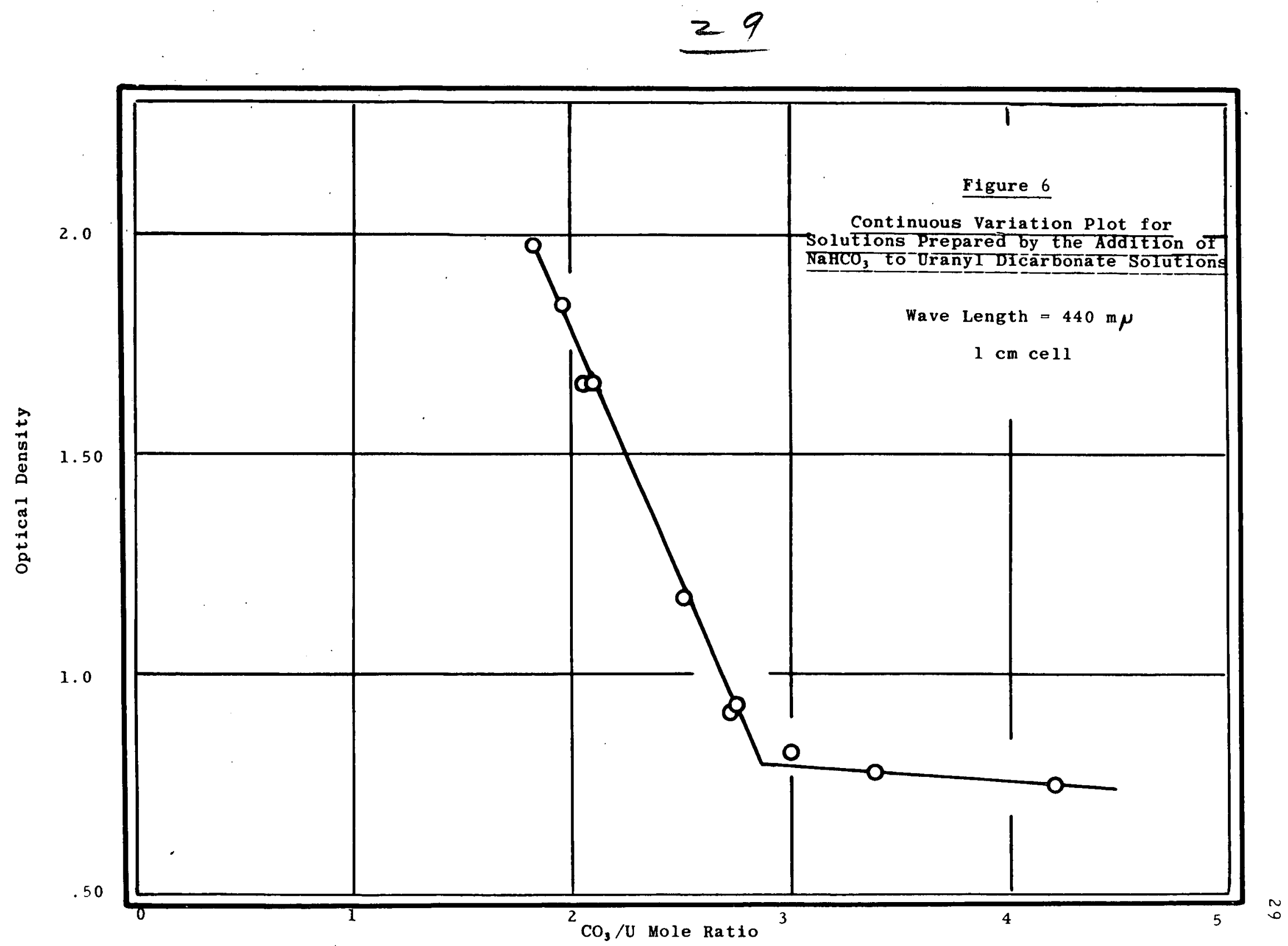


Table 13

Optical Densities of Sodium Üranyl Tricarbonate

Solutions in the Presence of Sodium Bicarbonate

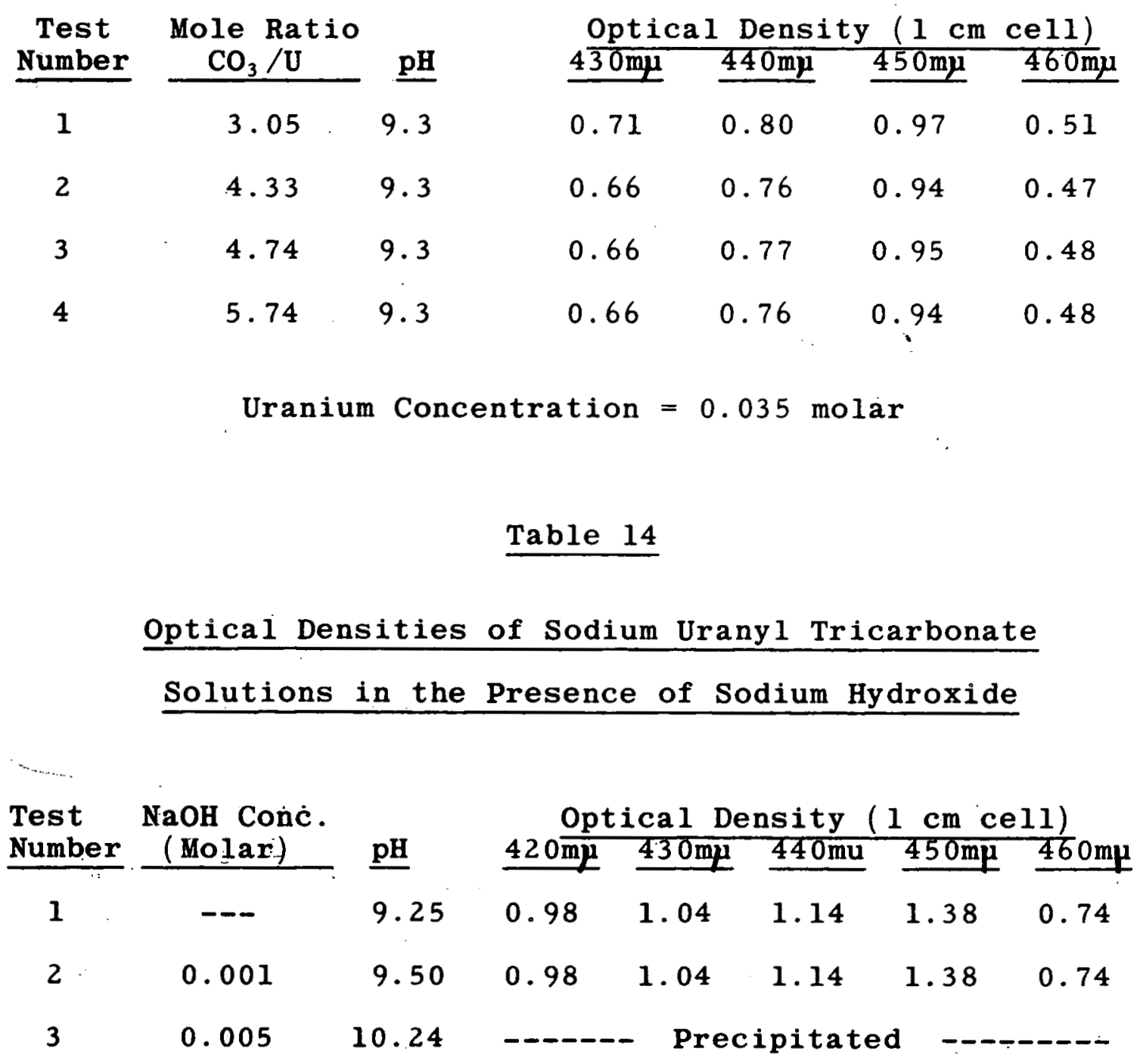

Uranium Concentration $=\cdot 0: 035$ molar 
of $\mathrm{CO}_{3} / \mathrm{U}=2$ and $\mathrm{Na} / \mathrm{U}=2$. If the assumption is made that these solutions contain a large amount of the third complex the optical and analytical evidence points to a complex in which $\mathrm{CO}_{3} / \mathrm{U}=\mathrm{Na} / \mathrm{U}=2$. In order to maintain this sodiumuranium-carbonate balance and a neutral pH, the formation of bicarbonate, bicarbonate-carbonate or hydroxy-carbonate complexes seems unlikely. The possibility of the presence of hydroxy-bicarbonate complex ions with a resultant

polymerization cannot by excluded, for preliminary dialysis experiments have shown that there is no diffusion through a cellophane membrane for solutions containing uranyl dicarbonate at the particular concentration studied. Since the only difference between carbonate and hydroxy-bicarbonate complexes is the presence of one or two molecules of water, it is extremely difficult to distinguish between the two types. The reactions of either complex would be expected to be identical and, for simplicity, the third complex ion of the uranium-carbonate system may be postulated as being

$$
\mathrm{UO}_{2}\left(\mathrm{CO}_{3}\right)_{2}^{-2}
$$

Assuming these three species, a series of equations may be expressed as follows:
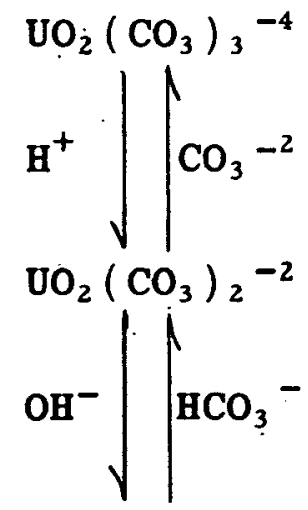<smiles></smiles>

Precipitation (uranates) 
The possibility of the existence of an ion having a carbonate-uranium mole ratio of $1, \mathrm{UO}_{2} \mathrm{OHCO}_{3}^{-}$, has been reported. 10 The present investigation has shown no optical evidence to support this existence and attempts to prepare the complex according to the reaction

$$
\mathrm{Na}_{2} \mathrm{CO}_{3}+2 \mathrm{UO}_{2} \mathrm{CO}_{3}+\mathrm{H}_{2} \underset{(\mathrm{bubbling})}{\stackrel{\mathrm{N}_{2}}{\longrightarrow}} 2 \mathrm{NaUO}_{2} \mathrm{OHCO}_{3}+\mathrm{CO}_{2}
$$

have proven unsuccessful. Preparation of $\mathrm{Na}_{2} \mathrm{U}_{2} \mathrm{O}_{7}$ and its utilization in experiments suggested by the following equation

$$
\mathrm{Na}_{2} \mathrm{U}_{2} \mathrm{O}_{7}+2 \mathrm{CO}_{2}+\mathrm{H}_{2} \mathrm{O} \rightarrow 2 \mathrm{NaUO}_{2} \mathrm{OHCO}_{3}
$$

is being considered.

Adsorption spectra typical of those encountered in solutions of the carbonate uranium system have been reproduced and compared with one for $\mathrm{UO}_{2}\left(\mathrm{NO}_{3}\right)_{2}$ on Figure 7. Each of these spectra has been taken for solutions which have identical uranium concentrations of 0.034 molar. It may be observed that the presence of carbonate causes a shift in the spectrum toward the red with an enhancement of color. The maxima of the curve for $\mathrm{CO}_{3} / \mathrm{U}=3.0$ occurring at 426 , $437,451,465 \mathrm{~m} \mu$ are typical of the tricarbonate ion. On going from $\mathrm{CO}_{3} / \mathrm{U}=3.0$ to $\mathrm{CO}_{3} / \mathrm{U}=2.0$ there is an additional increase in color, a slight shift to the red and a decrease in the relative sizes of the two maxima at. 426 and 465 with respect to those at 437 and 451 . The wave form shown by the solution having $\mathrm{CO}_{3} / \mathrm{U}=0.5$ has only one pronounced peak and resembles closely the spectrum which is given by solutions in which the uranyl ion has hydrolyzed or dimerized.

\section{THE DISTRIBUTION OF CARBONATE-COMPLEXED URANIUM AS DETERMINED}

\section{FROM THE $\mathrm{CO}_{2}$ PRESSURE ABOVE URANIUM-CARBONATE SOLUTIONS}

In order to calculate the constants for dissociation of the uranium carbonate complexes, a system has been devised for the determination of the concentration of each of these species in solutions containing them. This system involves the measurement of the pressure of $\mathrm{CO}_{2}$ existing above uranium 


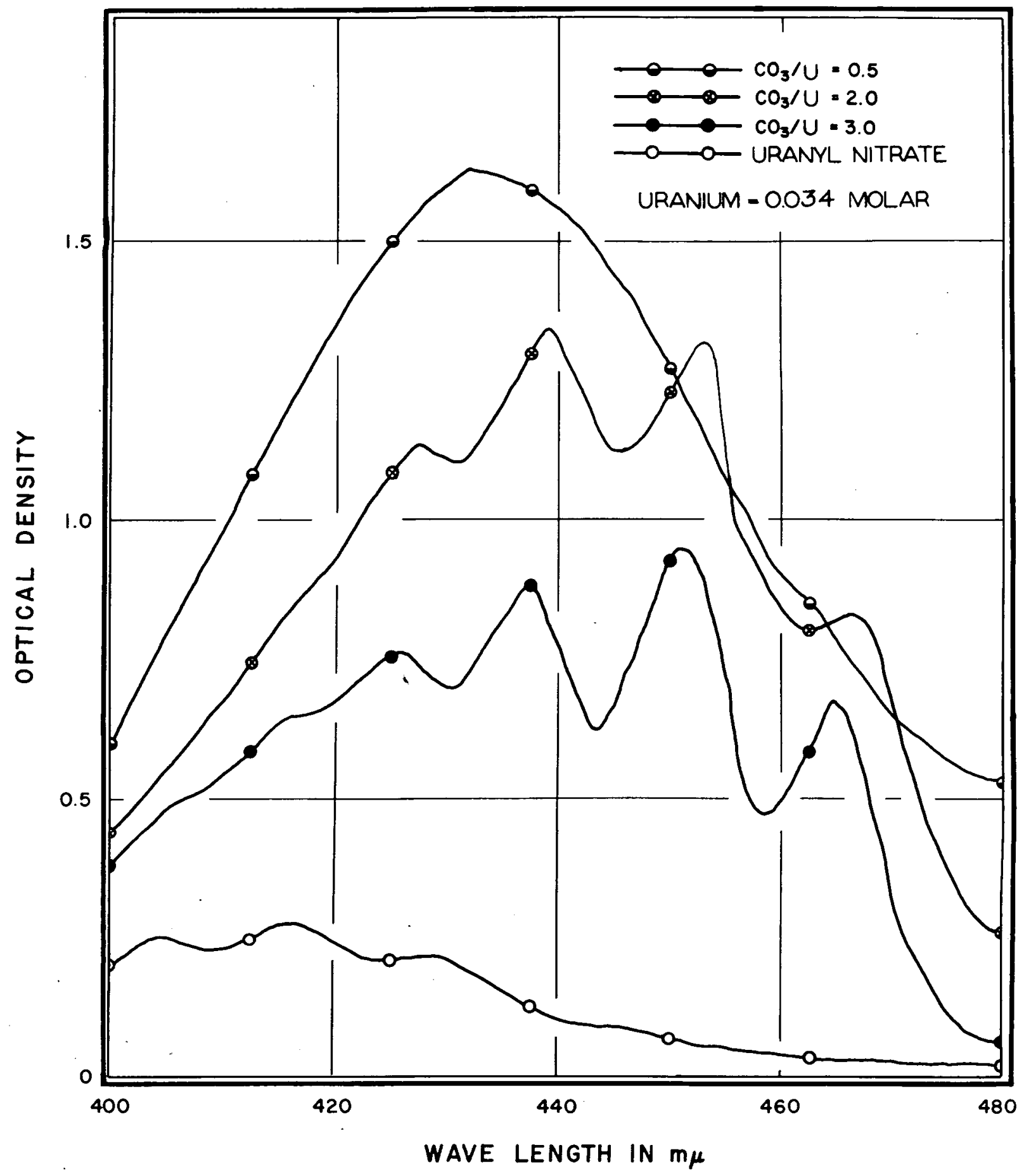

FIGURE 7. TYPICAL ABSORPTION SPECTRA FOR THE CARBONATE - URANIUM SYSTEM 
carbonate solutions and the correlation of this pressure with the amount of uncomplexed carbonate in solution $\left(\mathrm{CO}_{2}, \mathrm{HCO}_{3}\right.$, and $\left.\mathrm{CO}_{3}-2\right)$. At the present time, this scheme must still be considered as being in its early stages of development and hence the results obtained by this method and presented in the following section are, at best, approximate. They will remain so until a more detailed theoretical and mathematical treatment is available, until improved equipment and technique are developed and until very exacting analytical determinations can be made.

To apply this method to the general case of the carbonateuranium solution, the following equations have been formulated

The total distribution of uranium,

$$
\mathrm{C}_{\text {uranium }}=\mathrm{C}_{3}+\mathrm{C}_{2}+2 \mathrm{C}_{\mathrm{n}}+\mathrm{C}_{+}
$$

where

$$
\begin{aligned}
\mathrm{C}_{3}= & \text { molar conc. of tricarbonate, } \mathrm{UO}_{2}\left(\mathrm{CO}_{3}\right)_{3}-4 \\
\mathrm{C}_{2}= & \text { molar conc. of dicarbonate, } \mathrm{UO}_{2}\left(\mathrm{CO}_{3}\right)_{2}-2 \\
\mathrm{C}_{\mathrm{n}}= & \text { molar conc. of semicarbonate, } \mathrm{U}_{2} \mathrm{O}_{5} \mathrm{OHCO}_{3}- \\
\mathrm{C}_{+}= & \text {molar conc. of hydrolyzed uranium, or uranyl } \\
& \text { ion, } \mathrm{UO}_{2}+2 \text {, } \mathrm{U}_{2} \mathrm{O}_{5}+2 \text {, etc. (negligible in } \\
& \text { solutions of di and tri-carbonates) }
\end{aligned}
$$

The distribution of carbonate

$$
C_{\text {carbonate }}=3 C_{3}+2 C_{2}+C_{n}+A
$$

where

$\mathrm{A}=$ carbonate occurring as free $\mathrm{CO}_{3}{ }^{-2}, \mathrm{HCO}_{3}-$, or $\mathrm{H}_{2} \mathrm{CO}_{3}$. (For convenience all dissolved $\mathrm{CO}_{2}$ is represented as $\mathrm{H}_{2} \mathrm{CO}_{3}$. If part or all remains as $\mathrm{CO}_{2}$ the calculations will not be affected.)

The concentration of cations,

$$
\mathrm{C}_{\text {cation }}=4 \mathrm{C}_{3}+2 \mathrm{C}_{2}+\mathrm{C}_{\mathrm{n}}+\mathrm{C}_{\mathrm{X}}+\mathrm{C}_{\mathrm{OH}^{-}}+\mathrm{B}
$$

where

$$
C_{X}=\text { Molar concentration of any non-complexing }
$$

$\mathrm{C}_{\mathrm{OH}^{-}}=$molar concentration of hydroxyl ion $=\frac{10^{-14}}{\mathrm{C}_{\mathrm{H}^{+}}}$

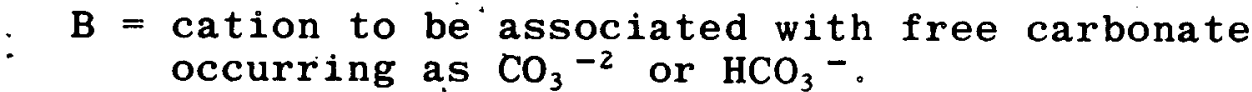


Analytical data is sufficient to yield values for $C_{\text {uranium, }} C_{c a t i o n}$ and $\mathrm{C}_{\mathrm{X}}$ while $\mathrm{C}_{\mathrm{OH}^{-}}$may be determined from a pH measurement. The evaluation of the correction terms, $A$ and $B$, is made by means of calculation involving the dissociation equilibria of carbonic acid and the pressure of $\mathrm{CO}_{2}$ existing above the solution.

Let

$$
\mathbf{K}^{\prime}=\frac{\left(\mathrm{HCO}_{3}^{-}\right)\left(\mathrm{H}^{+}\right)}{\left(\mathrm{H}_{2} \mathrm{CO}_{3}\right)}
$$

and

$$
\mathbf{K}^{\prime \prime}=\frac{\left(\mathrm{CO}_{3}^{-2}\right)\left(\mathrm{H}^{+}\right)}{\left(\mathrm{HCO}_{3}^{-}\right)}
$$

so that

$$
\left(\mathrm{HCO}_{3}{ }^{-}\right)=\mathrm{H}_{2} \mathrm{CO}_{3}\left[\frac{\mathrm{K}^{\cdot}}{\left(\mathrm{H}^{+}\right)}\right]
$$

and

$$
\left(\mathrm{CO}_{3}^{-2}\right)=\mathrm{H}_{2} \mathrm{CO}_{3}\left[\frac{\mathrm{K}^{\prime} \mathrm{K}^{89}}{\left(\mathrm{H}^{+}\right)^{2}}\right]
$$

Define

$$
\begin{aligned}
& \mathrm{A} \equiv\left(\mathrm{H}_{2} \mathrm{CO}_{3}\right)+\left(\mathrm{CO}_{3}^{-2}\right)+\left(\mathrm{HCO}_{3}^{-}\right) \\
& \mathrm{B} \equiv 2\left(\mathrm{CO}_{3}^{-2}\right)+\left(\mathrm{HCO}_{3}^{-}\right)
\end{aligned}
$$

Substituting,

$$
\begin{aligned}
& A=\mathrm{H}_{2} \mathrm{CO}_{3}\left[1+\frac{\mathrm{K}^{\prime}}{\left(\mathrm{H}^{+}\right)}+\frac{\mathrm{K}^{\prime} \mathrm{K}^{\prime \prime}}{\left(\mathrm{H}^{+}\right)^{2}}\right] \\
& \mathrm{B}=\mathrm{H}_{2} \mathrm{CO}_{3}\left[\frac{\mathrm{K}^{\prime}}{\left(\mathrm{H}^{+}\right)}+\frac{2 \mathrm{~K}^{\prime} \mathrm{K}^{\prime \prime}}{\left(\mathrm{H}^{+}\right)^{2}}\right]
\end{aligned}
$$


The solubility of a gas in a given liquid can be expressed by means of Bunsen's absorption coefficient, $\alpha_{t}$, defined as the volume of a gas (in liters reduced to $0 \circ \mathrm{C}$ and $760 \mathrm{~mm}$ ) dissolved in one liter of the liquid at the temperature $t$ when the partial pressure of the gas in the gas phase is $-760 \mathrm{~mm}$. For $\mathrm{CO}_{2}$ in aqueous solutions of salts having appreciable variations in concentration, this coefficient has a fairly constant value of $\alpha_{25^{\circ}} \approx 0.7 .11$ Addition of acid to these solutions seems not to affect this value greatly. Thus, if the pressure of $\mathrm{CO}_{2}$ over a uraniumcarbonate solution is known, it appears possible to calculate at room temperature and atmospheric pressure the concentration of $\mathrm{H}_{2} \mathrm{CO}_{3}$ in the solution according to the following expression

$$
\begin{aligned}
\mathrm{H}_{2} \mathrm{CO}_{3} & =\frac{0.7 \text { liters } \mathrm{CO}_{2} / \text { liter solution }}{22.4 \text { liters } \mathrm{CO}_{2} / \text { mole }} \times \frac{\mathrm{PCO}_{2}}{760} \times \frac{273}{298} \\
& =3.74 \times 10^{-5} \mathrm{P}_{\mathrm{CO}_{2}} \text { moles/liter solution. }
\end{aligned}
$$

Equations (25a) and (26a) become

$$
\begin{aligned}
& A=3.74 \times 1.0^{-5} \dot{P}_{\mathrm{CO}_{2}}\left[1+\frac{\mathbf{K}^{p}}{\left(\mathrm{H}^{+}\right)}+\frac{\mathbf{K}^{\imath} \mathrm{K}^{\prime \prime}}{\left(\mathrm{H}^{+}\right)^{2}}\right] \\
& \mathbf{B}=3.74 \times 10^{-5} \mathbf{P}_{\mathrm{CO}_{2}}\left[\frac{\mathrm{K}^{\prime}}{\left(\mathrm{H}^{+}\right)}+2 \frac{\mathrm{K}^{\prime} \mathrm{K}^{\mathrm{ig}}}{\left(\mathrm{H}^{+}\right)^{2}}\right]
\end{aligned}
$$

Values of $K^{\prime}$ at different ionic strengths may be obtained from Table 15 .

\section{Table 15}

The First Dissociation Constant of $\mathrm{H}_{2} \mathrm{CO}_{3}$

\begin{tabular}{lc}
$\boldsymbol{\mu}$ & $\mathbf{K}^{\prime} \mathbf{X} 107$ \\
\cline { 2 - 2 } 0 & 4.45 \\
0.1 & 7.66 \\
0.5 & 8.78 \\
0.7 & 10.41 \\
1.0 & 10.88 \\
& 11.37
\end{tabular}


An equation relating $K^{\prime \prime}$ with ionic strength has been obtained ${ }^{13}$ for solutions of $\mathrm{CO}_{2}$ in $\mathrm{NaCl}$ and $\mathrm{KCl}$.

$$
\mathrm{pK}^{\prime \prime}=10: 320-\frac{2.02 \sqrt{\mu}}{1 .+\alpha \sqrt{\mu}}+B \mu
$$

where

$$
\text { for } \begin{array}{lll}
\mathrm{NaCl} 1 & \alpha=1.49 & B=0.055 \\
\mathrm{KC1} & \alpha=1.66 & B=0.143
\end{array}
$$

Use of equations (19), (20) and (21) or simplifications of these equations should allow the calculation of concentrations of tricarbonate, dicarbonate and semicarbonate present in carbonate uranium solutions, if the species postulated are the true ones, and if the assumptions made in the calculation of $A$ and $B$ are correct. As a check on the validity of these equations they have been applied to several hypothetical solutions which are prototypes of the ones actually encountered.

The first of these is a tricarbonate solution in which Ccation $_{\text {cation }} 4$ Curanium; $C_{\text {carbonate }}=2$ Curanium; $\mathrm{C}_{\mathbf{X}}=\mathrm{C}_{+}=0$; and $\mathrm{C}_{\mathrm{H}^{+}}=10^{-9}$. The expressions resulting from the simultaneous solution are as follows:

$$
\begin{aligned}
& C_{3}=\text { Curanium }+A-B \\
& C_{2}=C_{\text {uranium }}-\frac{7 A-5 B}{3} \\
& C_{n}=\frac{2 A-B}{3}
\end{aligned}
$$

This requires that $1.4<B / A<2.0$ in order to have real concentrations of all three species. Unfortunately, estimates of $A$ and $B$ from experimental data are such that $1.4>B / A>1.0$, a discrepancy which has not as yet been accounted for. Experimentally it has been observed that addition of $\mathrm{CO}_{2}$ to a tricarbonate solution does not affect the color of the solution even though there is an accompanying decrease in pH. This is interpreted as evidence that there is no appreciable formation of the highly colored semicarbonate in this process and consequently as an approximation it may be possible to eliminate the terms involving this ion and its concentration from equations (19), (20) and (21) when applying 
them to solutions having $\mathrm{CO}_{3} / \mathrm{U}$ mole ratios greater than 2.0 . Such a simplification results in very reasonable expressions for the concentrations of the tricarbonate and dicarbonate complexes,

$$
\begin{aligned}
& C_{3}=C_{\text {carbonate }}-2 C_{\text {uranium }}-A \\
& C_{2}=3 C_{\text {uranium }}-C_{\text {carbonate }}+A
\end{aligned}
$$

Application of the equations to a hypothetical solution having $\mathrm{CO}_{3} / \mathrm{U}=\mathrm{Na} / \mathrm{U}=2, \mathrm{C}_{+}$and $\mathrm{C}_{\mathrm{X}}=0$, and with a $\mathrm{pH}=7.0$ gives the following expressions for the concentrations of the three complex species.

$$
\begin{aligned}
& C_{3}=A-B \\
& C_{2}=C_{\text {uranium }}-\frac{7 A-5 B}{3} \\
& C_{n}=\frac{2 A-B}{3}
\end{aligned}
$$

This demands that $A>B$ which calculation will show to be true at $\mathrm{pH}$ values of 7 and slightly above, and therefore, these equations hold with no further approximations for solutions having $\mathrm{CO}_{3} / \mathrm{U}$ mole ratios of 2.0 or close to this value.

The necessity for consideration of other ions, $C_{+}$, containing uranium (e.g., the uranyl or dimerized uranyl ion) in solution having $\mathrm{CO}_{3} / \mathrm{U}$ levels of 0.5 complicates the system and additional equations are required for its complete solution. This preliminary investigation, therefore, neglects solutions having $\mathrm{CO}_{3} / \mathrm{U}$ mole ratios less than 1.8 .

Having established some of the limitations which must be imposed on these equations several experiments of an exploratory nature were performed. These were of two types, static and dynamic. The static tests were run on fairly concentrated dicarbonate solutions which were placed in a sealed vessel with provision for lsolating a known volume of the gasses above the solution. After sufficient time had elapsed for the solution to attain equilibrium with its atmosphere, the latter was forced through a $\mathrm{CO}_{2}$ absorption train by displacement with mercury. The pressure was determined by means of a simple gas-law calculation. The dynamic tests were 
conducted on samples which were bubbled with a nitrogen- $\mathrm{CO}_{2}$ mixture of known composition until equilibrium was reached. At this point, a known volume of the solution was removed from the bottom of the flask and dropped into the sulfuric acid boiler of a $\mathrm{CO}_{2}$ absorption train, and the total carbonate was determined. Table 16 presents the experimental data obtained from these tests.

\section{Table 16}

Analytical and Optical Data for Solutions in

Equilibrium with Measured $\mathrm{CO}_{2}$ Atmospheres

Test

Number

\begin{tabular}{lll} 
Number & $\mathrm{CO}_{3} / \mathrm{U}$ & $\mathrm{U}$ \\
\cline { 1 - 1 } 360 & 1.84 & 1.177 \\
342 & 1.83 & 0.344 \\
343 & 1.85 & 1.311 \\
$328-1$ & 2.00 & 0.534 \\
$328-2$ & 2.09 & 0.337
\end{tabular}

$357-1$

$357-2$

$348-3$

$357-3$

$357-4$

317

256-1

2.20
2.41
2.55
2.87
2.89
3.05
3.15

0.329

0.321

0.340

0.290

0.272

0.224

0.264

$\mathrm{CO}_{2}$ Atmospheres


Table 17

\section{Concentrations of Tricarbonate and Dicarbonate}

Ions in Solutions Having $2.20<\mathrm{CO}_{3} / \mathrm{U}<3.15$

Test

\begin{tabular}{|c|c|c|c|c|c|c|}
\hline $\begin{array}{c}\text { Test } \\
\text { Number } \\
\end{array}$ & $\mathrm{CO}_{3} / \mathrm{U}$ & $\begin{array}{c}\mu \\
\text { (approx.) } \\
\end{array}$ & A & B & $\underline{\mathrm{C}_{3}}$ & $\underline{\mathrm{C}_{2}}$ \\
\hline $\begin{array}{l}357-1 \\
357-2 \\
348-3 \\
357-3 \\
357-4 \\
317 \\
356-1\end{array}$ & $\begin{array}{l}2.20 \\
2.41 \\
2.55 \\
2.87 \\
2.89 \\
3.05 \\
3.15\end{array}$ & $\begin{array}{l}1.64 \\
1.85 \\
2.25 \\
2.35 \\
2.50 \\
1.96 \\
2.60\end{array}$ & $\begin{array}{l}0.039 \\
0.046 \\
0.138 \\
0.056 \\
0.071 \\
0.135 \\
0.089\end{array}$ & $\begin{array}{l}0.035 \\
0.043 \\
0.136 \\
0.053 \\
0.068 \\
0.107 \\
0.086\end{array}$ & $\begin{array}{l}0.028 \\
0.084 \\
0.050 \\
0.196 \\
0.173 \\
0.099 \\
0.215\end{array}$ & $\begin{array}{l}0.301 \\
0.237 \\
0.290 \\
0.094 \\
0.099 \\
0.125 \\
0.049\end{array}$ \\
\hline
\end{tabular}

As a check on the validity of the calculations, it is of interest to substitute the above concentrations in the equation for the optical density of the solution.

$$
\text { O.D. }=\ell\left[E_{2} C_{2}+E_{3} C_{3}\right]
$$

The extinction coefficient for the tricarbonate ion, $E_{3}$, may be calculated from the Beer's Law data of Table 3, Figure 2 , and has the value

$$
E_{3}=22 \text { at } 440 \mathrm{~m} \beta
$$

Using this value and the optical density data of Table 17, values have been obtained for the extinction coefficient of the dicarbonate ion, $E_{2}$, and these are given in Table 18.

Table 18

\begin{tabular}{lc} 
Extinction Coefficient of Uranyl Dicarbonate Ion \\
\hline Test No. & $\frac{E_{2}}{24.2}$ \\
$357-1$ & 22.8 \\
$357-2$ & 23.4 \\
$348-3$ & 24.2 \\
$357-3$ & 22.2 \\
$357-4$ & 22.6 \\
317 & 23.6 \\
$356-1$ & Average 23.4 at $440 \mathrm{mp}$
\end{tabular}


This value is reasonable when compared with the value of 34 obtained from the slope of the Beer's law data of Table 4 and Figure 3 , for it must be remembered that this curve shows the presence of semicarbonate ion as we 11 as dicarbonate ions in solutions and this presence gives a higher color than would be possible in a pure dicarbonate solution.

The greatest difficulty in the use of these equations lies in the necessity for division by small numbers which are, in turn, differences between small numbers. This is of importance in dilute solutions and places much emphasis on the accuracy of the analytical results. In particular, the use of equation (21) and the sodium analyses which it involves is most unsatisfactory. Unfortunately, application of equations (19), (20) and (21) to many of the more dilute test solutions having $\mathrm{CO}_{3} / \mathrm{U}$ mole ratios close to 2.0 results in improbable concentrations of the three complex species and for the extinction coefficient of the semicarbonate ion. For the more concentrated solutions of tests 360 and 343 (Table 16) the analytical and mathematical difficulties are minimized and reasonable values were obtained for the concentrations. These are presented in Table 19.

The extinction coefficient for the semicarbonate ion, $E_{n}$, was calculated from the data of this table according to the following equation

$$
\text { O.D. }=\boldsymbol{l}\left(\mathrm{E}_{3} \mathrm{C}_{3}+\mathrm{E}_{2} \mathrm{C}_{2}+\mathrm{E}_{\mathrm{n}} \mathrm{C}_{\mathrm{n}}\right)
$$

and values for $E_{n}$ appear also in Table 19.

Table 19

Concentrations of the Complex Species and

The Extinction Coefficient of the Semicarbonate

Ion in Concentrated Solutions

Test

Number

360

343

$$
\begin{gathered}
\mathrm{CO}_{3} / \mathrm{U} \\
1.8 \\
1.8
\end{gathered}
$$

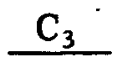

.139

.213

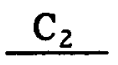

.814

.816

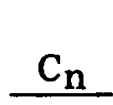

.112

.141
En $440 \mathrm{~m} \mu$

218

It is possible, by making an estimate of $E_{n}$, to use equation (36) in place of equation (21) and thus alleviate some of the analytical difficulties. Such an estimate has 
been made from the data of Table 19. Assume that

$$
E_{\mathbf{n}}=250 \text { at } 440 \mathrm{~m} \mu
$$

Comparison of this value with the data of Figure 1 at the $\mathrm{CO}_{3} / \mathrm{U}$ mole ratio of 0.5 shows that its magnitude is not improbable for the optical density at that point requires $E_{n}$ to be at least 220 . Furthermore, it has been shown that variation of this value by +20 will not affect the following calculations to an appreciable extent.

With this quantity assumed, equations (19), (20) and (36)

may be used to calculate the concentrations of the three complex species. The results appear in Table 20 .

Table 20

The Concentration of the Three Uranium-Carbonate

Complexes in Solutions Having $1.8<\mathrm{CO}_{3} / \mathrm{U}<2.1$

Test

\begin{tabular}{lllllllll}
$\begin{array}{c}\text { Test } \\
\text { Number }\end{array}$ & $\mathrm{CO}_{3} / \mathrm{U}$ & $\begin{array}{c}\mu \\
\text { (approx.) }\end{array}$ & & $\mathrm{A}$ & $\mathrm{B}$ & $\underline{\mathrm{C}_{3}}$ & $\underline{\mathrm{C}_{2}}$ & \multicolumn{1}{c}{$\mathrm{C}_{\mathbf{n}}$} \\
360 & 1.84 & 3.2 & & .008 & .007 & 0.161 & 0.778 & 0.119 \\
342 & 1.83 & 0.95 & .010 & .010 & 0.054 & 0.322 & 0.018 \\
343 & 1.85 & 3.6 & .010 & .009 & 0.145 & 0.930 & 0.118 \\
$328-1$ & 2.00 & 1.59 & .017 & .013 & 0.002 & 0.520 & 0.006 \\
$328-2$ & 2.09 & 1.05 & .020 & .016 & 0.015 & 0.320 & 0.001
\end{tabular}

*See Table 16

Having obtained these concentrations, approximate calculations can be made for the stability of these ions toward decomposition according to the mechanisms proposed in the next section. 


\section{PRELIMINARY CALCULATIONS FOR THE DISSOCIATION}

CONSTANTS OF THE URANYL-CARBONATE COMPLEX IONS

The following mechanism is proposed for the dissociation of the uranyl tricarbonate ion.

$$
\mathrm{UO}_{2}\left(\mathrm{CO}_{3}\right)_{3}^{-4} \rightleftarrows \mathrm{UO}_{2}\left(\mathrm{CO}_{2}\right)_{2}^{-2}+\mathrm{CO}_{3}^{-2}
$$

The corresponding dissociation constant, $\underline{K_{3}}$, for this reaction would be

$$
\mathrm{K}_{3}=\frac{\left(\mathrm{C}_{2}\right)\left(\mathrm{CCO}_{3}-2\right)}{\left(\mathrm{C}_{3}\right)}
$$

Values for $C_{2}$ and $C_{3}$ have been calculated in the previous section, and according to equations (24) athd (27)

$$
\mathrm{C}_{\mathrm{CO}_{3}}{ }^{-2}=3.74 \times 10^{-5} \mathrm{PCO}_{2}\left[\frac{\mathrm{K}^{\prime} \mathrm{K}^{\prime \prime}}{\left(\mathrm{H}^{+}\right)^{2}}\right]
$$

where

$$
\begin{aligned}
K^{\prime}= & \text { first dissociation constant of } \mathrm{H}_{2} \mathrm{CO}_{3} \text { (Table 15) } \\
\mathbf{K}^{\prime \prime}= & \text { second dissociation constant of } \mathrm{H}_{2} \mathrm{CO}_{3} \text { (Equation } \\
& (28))
\end{aligned}
$$

Results of calculations using data of Tables 17 and 20 are shown on Table 21. The average value obtained for $\underline{K}_{3}$ is

$$
\mathrm{K}_{3}=4.5 \times 10^{-7}
$$

Similar calculations have been made for the dissociation of the uranyl dicarbonate ion according to the reaction

$$
2 \mathrm{UO}_{2}\left(\mathrm{CO}_{3}\right)_{2}^{-2}+2 \mathrm{H}_{2} \mathrm{O}_{2} \rightleftarrows \mathrm{U}_{2} \mathrm{O}_{5} \mathrm{OHCO}_{3}^{-}+3 \mathrm{HCO}_{3}^{-}
$$

and for the dissociation constant, $K_{2}$

$$
\mathrm{K}_{2}=\frac{\left(\mathrm{C}_{\mathrm{n}}\right)\left(\mathrm{C}_{\mathrm{HCO}_{3}}\right)^{3}}{\left(\mathrm{C}_{2}\right)^{2}}
$$

Since according to equations (22a) and (27)

$$
\mathrm{CHCO}_{3}{ }^{-}=3.74 \times 10^{-5} \mathrm{P}_{\mathrm{CO}_{2}} \frac{\mathrm{K}^{\prime}}{\left(\mathrm{H}^{+}\right)}
$$


Results from calculations of the dissociation constant of the uranyl dicarbonate ion are shown in Table 22. The average value obtained for $K_{2}$ is $K_{2}=8.4 \times 10^{-8}$.

The limitations of this method have been discussed and in view of these restrictions, it must be remembered that these dissociation constants are to be considered as preliminary values only. 
Table 21

The Dissociation Constant for Uranyl

Tricarbonate Ion According to Equation 38

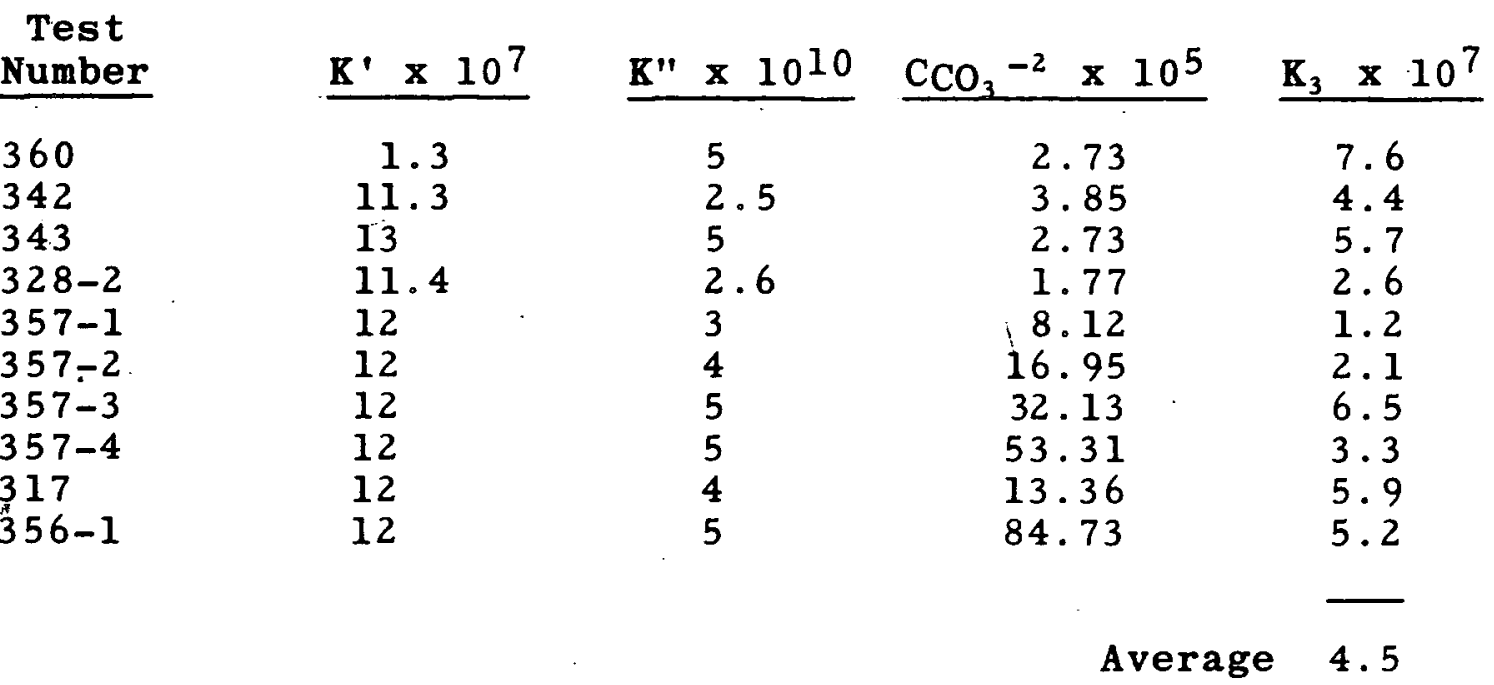

Table 22

The Dissociation Constant of Uranyl Dicarbonate According to Equation 41

Test

Number

36.0

342

343

328-1

328-2

\begin{tabular}{c}
$\mathrm{K}^{\cdot} \times 10^{7}$ \\
\hline 13 \\
11.3 \\
13 \\
12 \\
11
\end{tabular}

$\mathrm{CHCO}_{3}-\mathrm{x}$
7.18
9.69
8.88
13.24
16.210

16.10
$\underline{K_{2} \times 10^{8}}$

7.3

15.8

9.6

5.2

4.2

Average 8.4 


\section{SUMMARY}

1. Additional evidence for the existence in solution of the uranyl tricarbonate ion, $\mathrm{UO}_{2}\left(\mathrm{CO}_{3}\right)_{3}^{-4}$, has been obtained by continuous variation spectrophotometric methods.

2. The presence of two additional complex ions of the uranium carbonate system has been demonstrated. These are postulated as being the dicarbonate ion, $\mathrm{UO}_{2}\left(\mathrm{CO}_{3}\right)_{3}-2$, and the semicarbonate ion, $\mathrm{U}_{2} \mathrm{O}_{5} \mathrm{OHCO}_{3}-$ (or polymers thereof).

3. The tricarbonate ion is the complex which is most favored in carbonate solutions $(\mathrm{pH}>8)$ and is stable in solutions containing sodium chloride, sodium hydroxide, sodium bicarbonate and large excesses of sodium carbonate. Solutions of sodium uranyl tricarbonate obey Beer's law over its entire range of solubility in water.

4. The optical den'sity and composition of a solution of sodium uranyl dicarbonate, in contrast to the stable tricarbonate, changes with any change in $\mathrm{pH}$. Dicarbonate solutions lose $\mathrm{CO}_{2}$ readily when bubbled with $\mathrm{N}_{2}$.

5. Addition of $\mathrm{NaHCO}_{3}$ to uranyl dicarbonate solutions in the amount required to give $\mathrm{CO}_{3} / \mathrm{U}=3.0$ yields a solution having approximately the optical density shown by a tricarbonate solution of the same uranium concentration. The lower $\mathrm{pH}$ of this solution indicates possible formation of a carbonate-bicarbonate complex which as yet cannot be distinguished from the usual tricarbonate one.

6. The concentrations of each of the ions in various solutions have been calculated by means of a scheme involving the measurement of the pressure of $\mathrm{CO}_{2}$ over these solutions and subsequent calculation of the amount of uncomplexed carbonate in solution. Approximations have been made for the dissociation of the tricarbonate ion and the dicarbonate ion according to the following mechanisms:

$$
\begin{aligned}
& \mathrm{UO}_{2}\left(\mathrm{CO}_{3}\right)_{3}^{-4} \stackrel{\mathrm{K}_{3}}{\rightleftarrows} \mathrm{UO}_{2}\left(\mathrm{CO}_{3}\right)_{2}^{-2}+\mathrm{CO}_{3}^{-2} ; \\
& \mathbf{K}_{3}=4: 5 \times 10^{-7} \\
& 2 \mathrm{UO}_{2}\left(\mathrm{CO}_{3}\right)_{2}^{-2}+2 \mathrm{H}_{2} \mathrm{O} \stackrel{\mathrm{K}_{2}}{\rightleftarrows} \mathrm{U}_{2} \mathrm{O}_{5} \mathrm{OHCO}_{3}^{-}+3 \mathrm{HCO}_{3} ; \\
& \mathrm{K}_{2}=8.4 \times 10^{-8}
\end{aligned}
$$




\section{REFERENCES}

1. "Progress Report, ORNL - Y-12 Area, January 1, 1950 March 31, 1950." Document Y-585.

2. Blake, C. A., Lowrie, R. S., Hill, D. G. and Brown, K. B., "Studies in the Carbonate-Uranium System, Part I. Investigations in the Four Component System: $\mathrm{UO}_{3}$, $\mathrm{Na}_{2} \mathrm{O}, \mathrm{CO}_{2}, \mathrm{H}_{2} \mathrm{O} . "$ ORNL $-\mathrm{Y}-12$ Area. Document $\mathrm{Y}-673$. December 14,1950 .

3. Brown, K. B. and Coleman, C. F., "The Uranium Chemistry of Raw Materials," Document $\mathrm{Y}-622$. June 22, 1950.

4. Job, Ann. Chem. (10) 9, 113 (1928).

Vosburgh, W. C. and Cooper, J. R., J. Am. Chem. Soc. $63,437(1941)$.

5. Yoe, J. H. and Jones, A. L., Ind. Eng. Chem. Anal. Ed. 16, 111 (1944).

6. Best, R. J., Laub, D., and L. G. Longsworth, "The Measurement and Interpretation of $\mathrm{pH}$ and Conductance Values of Aqueous Solutions of Uranyl Salts," Rockefeller Institute for Medical Research, A-380, November 24,1942 .

7. Sutton, J., J. Chem. Soc. 5 , 275 (1949)。

8. Brintzinger, Naturwissenschaften 18, 354-5 (1930).

9. Kalauch, C., Kolloid Z. 112, 275 (1949).

10. Bersohn, R. and Brady, E. L., "A Chemical study of Hexavalent Uranium Compounds in Sodium Hydroxide, Sodium Carbonate and Sodium Bicarbonate Solutions," Mon C-109, March 1, 1946.

11. International Critical Tables $\underline{3}, 279$ (1928).

12. Harned, H. S: and Bonner, J. Am. Chem. Soc. 67, $1026-31$ (1945).

13. Nasanev, Reino, Sumomen Kemistilehti 19B, 90 (1946). 